\title{
An In Vitro Study of the Interaction of the Chemotherapeutic Drug Actinomycin D with lung Cancer Cell Lines Using Raman Micro- Spectroscopy
}

\author{
Zeineb Farhane \\ Technological University Dublin \\ Hugh J. Byrne \\ Technological University Dublin, hugh.byrne@tudublin.ie \\ Franck Bonnier \\ Technological University Dublin, Franck.Bonnier@tudublin.ie
}

Follow this and additional works at: https://arrow.tudublin.ie/radart

Part of the Medicine and Health Sciences Commons

\section{Recommended Citation}

Farhane, Z., Bonnier, F. and Byrne, H.J. (2017). An in vitro study of the interaction of the chemotherapeutic drug Actinomycin D with lung cancer cell lines using Raman micro-spectroscopy. Journal of Biophotonics, Jul 13, Epub ahead of print. doi:10.1002/jbio.201700112

This Article is brought to you for free and open access by the Radiation and Environmental Science Centre at ARROW@TU Dublin. It has been accepted for inclusion in Articles by an authorized administrator of ARROW@TU Dublin. For more information, please contact arrow.admin@tudublin.ie, aisling.coyne@tudublin.ie, gerard.connolly@tudublin.ie.

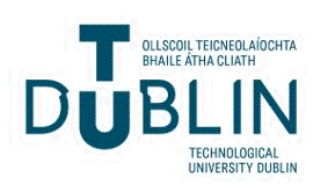




\title{
Doxorubicin kinetics and effects on lung cancer cell lines using in vitro Raman micro-spectroscopy: Binding signatures, Drug resistance and DNA repair
}

\author{
Z.Farhane $^{1,2 *}$, F.Bonnier $^{3}$, O.Howe ${ }^{4}$, A.Casey ${ }^{1}$ and H.J.Byrne ${ }^{1}$
}

${ }^{1}$ FOCAS Research Institute, Dublin Institute of Technology, Kevin Street, Dublin 8, Ireland.

${ }^{2}$ School of Physics, Dublin Institute of Technology, Kevin Street, Dublin 8, Ireland

${ }^{3}$ Université François-Rabelais de Tours, Faculty of Pharmacy, EA 6295 Nanomédicaments et Nanosondes, 31 avenue Monge, 37200 Tours, France

${ }^{4}$ School of Biological Sciences, Dublin Institute of Technology, Kevin Street, Dublin 8, Ireland.

*Corresponding author: zeineb.farhane@ mydit.ie

\begin{abstract}
:
Raman micro-spectroscopy is a non-invasive analytical tool, whose potential in cellular analysis and monitoring drug mechanisms of action has already been demonstrated, and which can potentially be used in pre-clinical and clinical applications for the prediction of chemotherapeutic efficacy. To further investigate such potential clinical application, it is important to demonstrate its capability to differentiate drug mechanisms of action and cellular resistances. Using the example of Doxorubicin (DOX), in this study, it was used to probe the cellular uptake, signatures of chemical binding and subsequent cellular responses, of the chemotherapeutic drug in two lung cancer cell lines, A549 and Calu-1. Multivariate statistical analysis was used to elucidate the spectroscopic signatures associated with DOX uptake and subcellular interaction. Biomarkers related to DNA damage and repair, and mechanisms leading to apoptosis were also measured and correlated to Raman spectral profiles. Results confirm the potential of Raman spectroscopic profiling to elucidate both drug kinetics and pharmacodynamics and differentiate cellular drug resistance associated with different subcellular accumulation rates and subsequent cellular response to DNA damage, pointing towards a better understanding of drug resistance for personalised targeted treatment.
\end{abstract}




\section{Abstract Figure:}
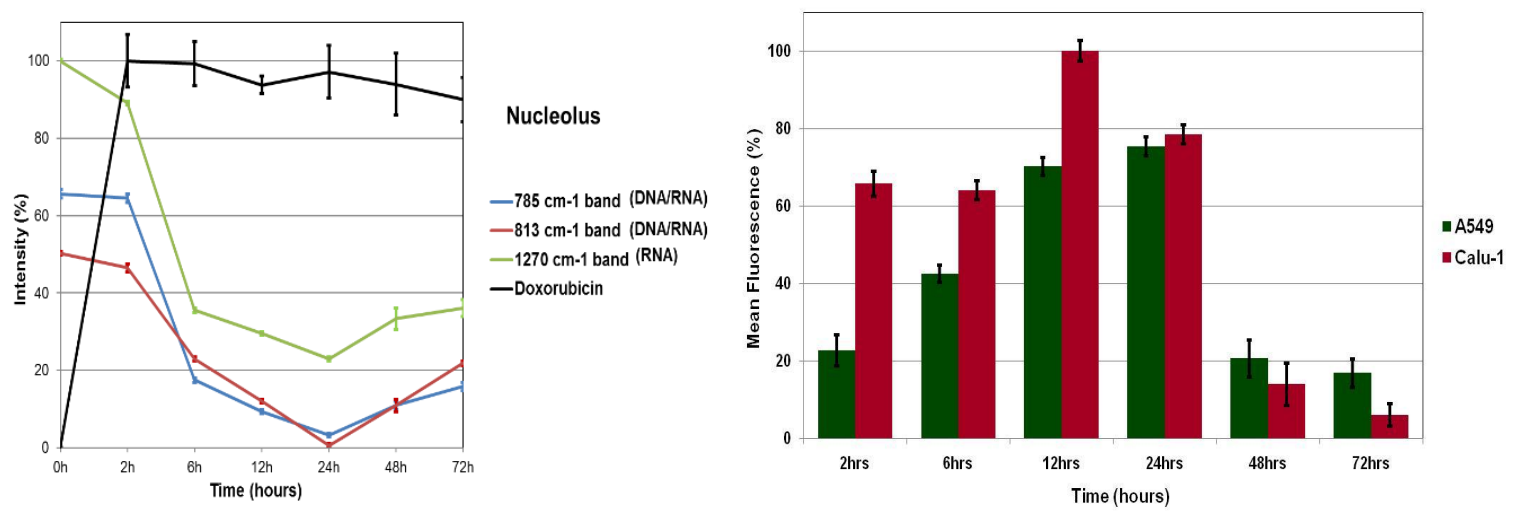

DNA damage and repair measured by Raman micro-spectroscopy and Mean Fluorescence of $\gamma \mathrm{H} 2 \mathrm{AX}$ after DOX exposure. Intensities expressed on percentage according to the maximum value for both cell lines.

\section{Short title:}

Doxorubicin kinetics and effects on lung cancer cell lines: Raman, Binding signatures, Drug resistance and DNA repair

Z. Farhane et al.

Keywords: Raman micro-spectroscopy, Doxorubicin, Cytotoxicity, lung cancer cell lines, bind signature, DNA repair. 


\section{Introduction:}

In the continued search for more effective chemotherapeutic treatments, there is a concomitant need for the development of improved screening techniques, particularly at the pre-clinical stage. Development of a new drug product from start to end is a very long process, taking on average 12 years, and costing, on average, $\$ 1.2$ billion per product [1-3].

EU Directive-2010/63/EU on the replacement, reduction and refinement of animal experimentation has prioritised the development of rapid, cost effective in vitro techniques for toxicological and pharmaceutical screening applications, amongst others.

High Throughput Screening techniques allow for the evaluation of multiple biochemical and morphological parameters in cells based on image analysis of morphological changes or monitoring multiple fluorescently labelled species/processes in a cellular population (Flow Cytometry) or at a subcellular level (Confocal Microscopy) [4]. Notably, however, such screening and analytical techniques are phenomenological rather than molecularly specific and thus are limited in their ability to elucidate the underlying mechanisms. Alternative, high content assaying techniques for in vitro cytological screening and analysis are therefore desirable.

Furthermore, despite the increased understanding of cancer biology and cellular drug mechanisms, all patients have a varied response to chemotherapeutic treatment and can develop adverse reactions and resistance to many approved drugs on the market. As an example, lung cancer remains the most common cause of cancer death worldwide $[5,6]$, despite the recent significant process in treatment and prevention $[7,8]$ and chemotherapeutic resistance is a major cause of treatment failure [9]. This highlights the need for personalised predictive testing to identify and characterise clinical biomarkers related either to the drug effects or to patient resistance. The development of an analytical tool for prediction of chemosensitivity, either in pre-clinical or diagnostic stages, is of great importance in order to adapt cancer treatment for each individual patient $[10,11]$.

Raman micro-spectroscopy is an analytical technique whose potential for biological analysis has already been demonstrated [12-14]. Therefore, it can be considered as a potential candidate for exploring pre-clinical drug development and clinical applications, by identifying signatures of drug mechanisms of interaction and even of cell dependent drug at a subcellular level.

As a proof of concept, a commercialy available drug Doxorubicin (DOX) is used in this study to demonstrate the potential of Raman micro-spectroscopy to monitor the uptake, interaction 
mechanisms and subsequent cellular responses, for pre-clinicial screening, as well as to differentiate the responses of two different cell lines, identifying markers of drug resistance, and therefore its potential as a companion diagnostic tool for personalized medicine. DOX is an anthracycline widely used in chemotherapy for the treatment of various human cancers and aggressive tumours $[15,16]$, despite its serious side effects, principally cardiotoxicity, and a not fully understood mechanism of action [17-19]. In previous in vitro reports, different relative contributions of subcellular processes have been observed, depending on cell line, [20] including ROS production, intercalation between nucleic base pairs and Topoisomerase II inhibition, blocking of DNA replication $[17,21]$ and induction of DNA double stand breaks (DSB) by nucleosome turnover increase, leading to cellular apoptosis [22-24]. DSB induce a DNA damage response (DDR) which can be visualised locally as an accumulation of repair proteins, known as nuclear foci [25] and chromatin modification acting as an adaptor attracting and localizing retention of DNA repair proteins. The cellular DNA damage and repair capacity influences the effects of an anticancer drug [26] and can be used as a biomarker of chemotherapeutic efficacy and resistance [27]. Moreover, resistance to apoptosis, programmed cell death, by either increase of apoptosis inhibitor protein or, higher tolerance to DNA damage or DNA repair, is associated with chemoresistance [18] and a poor clinical prognosis in cancer therapy and can be used as a marker for individualised treatment [28].

The present study expands the provious work exploring the use of Raman micro-spectroscopy to monitor DOX effects and cellular responses in vitro $[17,20]$ to a comparison of the uptake kinetics and responses of two different histological subtype cell lines, A549 and Calu-1. In order to extract biological information contained in Raman spectra, multivariate data analysis consising of Principal Component Analysis (PCA), Partial Last Square Regression (PLSR) and Independent Component Analysis (ICA) is used. Raman investigations are supported by cytotoxicity assays; apoptotic marker of nuclear condensation, specific anti-apoptotic protein (bcl-2) and DNA damage and repair by measurement of $\gamma \mathrm{H} 2 \mathrm{AX}$, to identify different DOX sensitivities, monitor cellular uptake and response mechanisms. 


\section{Materials and methods:}

\subsection{Materials:}

A549 human lung adenocarcinoma cells with the alveolar type II phenotype were obtained from ATTC (Manassas, VA, USA) and Calu-1 human lung epidermoid carcinoma cell line, was kindly provided by Dr. Josep Sulé-Suso, Institute for Science \& Technology in Medicine, Keele University, Guy Hilton Research Centre UK and Cancer Centre, Royal Stoke University Hospital, University Hospitals of North Midlands, UK.

A Doxorubicin stock solution of concentration $17.25 \mathrm{mM}$ was prepared by dilution of Doxorubicin hydrochloride ${ }^{\circledR}$ powder (Sigma Life Sciences, Ireland) in $1 \mathrm{~mL}$ sterile water.

Alamar blue (AB) (10X ready to use solution) and 3-[4,5-dimethylthiazol-2-yl]-2,5-diphenyl tetrazolium bromide (MTT) were obtained from Sigma Aldrich, Ireland.

For cytotoxicity assays, an AB/MTT solution, $1.5 \mathrm{~mL}$ of $\mathrm{AB}$ and $3 \mathrm{~mL}$ of MTT stock solution $(2.5 \mathrm{mg} / \mathrm{mL}, 25 \mathrm{mg} \mathrm{MTT} / 10 \mathrm{~mL} \mathrm{PBS})$ in $30 \mathrm{~mL}$ of fresh medium was prepared prior to performing the assays.

Nucred ${ }^{\circledR}$ live 647 Ready Probes ${ }^{\circledR}$ Reagent, used to image the cellular nuclear condensation, the fixation/permeabilization kit, BD Cytofix/Cytoperm (BD 554714), and FITC Mouse AntiHuman bcl-2 set with an IgG1 isotype control (BD 556357) was purchased from BioSciences, Ireland.

$\gamma \mathrm{H} 2 \mathrm{AX}$ reagents, Alexa Fluor ${ }^{\circledR} 647$ anti H2AX phospho (Ser 139) and Alexa Fluor ${ }^{\circledR} 647$ mouse IgG1 isotype control (ICFC), Biolegends, were supplied through Medical Supply Company Ltd., Ireland.

\subsection{Cell culture}

A549 cells were cultured in DMEM-F12 with $10 \%$ foetal bovine serum (FBS) and Calu-1 cells in RPMI with $10 \% \mathrm{FBS}$, both at $37^{\circ} \mathrm{C}$ in a humidified atmosphere containing $5 \% \mathrm{CO}_{2}$ and cells were split every two days to maintain $\sim 60 \%$ confluency.

For Cytotoxicity assays, Confocal Laser Scanning Fluorescence Microscopy (CLSM) and Raman micro spectroscopic analysis, the cell number was determined using a Beckman Coulter Particle Count and Size Analysis ${ }^{\circledR}$ Z2 Cell Counter. 


\subsection{Cytotoxicity assays:}

$\mathrm{AB}$ and MTT assays were performed in 96 well plates and a total number of $1 \times 10^{5}$ cells $\left(4 \times 10^{3}\right.$ cells $\left./ \mathrm{mL}\right), 1 \times 10^{4}\left(4 \times 10^{2}\right.$ cells $\left./ \mathrm{mL}\right)$ and $5 \times 10^{3}$ cells $\left(2 \times 10^{2}\right.$ cells $\left./ \mathrm{mL}\right)$, respectively for 0-24hrs, 48hrs and 72hrs, with three replicate plates of each. After $24 \mathrm{hrs}$ incubation, plates were washed with phosphate buffered saline solution (PBS) and DOX was added in a concentration range from $0 \mu \mathrm{M}$ (as a control) to $50 \mu \mathrm{M}$.

$\mathrm{AB}$ and MTT assays were both measured with a Cytotox SpectraMax ${ }^{\circledR} \mathrm{M} 3$ plate reader using Soft Max ${ }^{\circledR}$ Pro 6.2.2 software. After 6, 24, 48 and 72 hrs incubation in DOX, plates were washed with PBS and $100 \mu \mathrm{L}$ of $\mathrm{AB} / \mathrm{MTT}$ solution were added to each well. Plates were then incubated for 3 hours and $\mathrm{AB}$ fluorescence was measured first in the plate reader using 540 $\mathrm{nm}$ excitation and $595 \mathrm{~nm}$ emission, then the medium was removed, the plates were washed with PBS and 100 $\mu$ L of DMSO (Dimethyl sulfoxide) were added in each well.

MTT absorbance was read at 570nm.

All cytotoxicity assays were made in triplicate and repeated three times and viability data was fitted by a four parameter Hill equation analysis using SigmaPlot 10.0, to yield values of the mean inhibitory concentration, $\mathrm{IC}_{50}$.

\subsection{Raman micro-spectroscopy:}

Cells ( 1x 10 $/$ window) were seeded and incubated on $\mathrm{CaF}_{2}$ windows (Crystan Ltd, UK) for $24 \mathrm{hrs}$ for both control and exposure to DOX. The medium was then removed and samples were rinsed twice with sterile PBS and covered with DOX at each corresponding $\mathrm{IC}_{50}$ inhibitory concentration, adjusted to the cell number [29]. After each incubation period, 2, 6, 12, 24, 48 and 72 hrs, cells were washed twice with sterile PBS and fixed in formalin (4\%, $15 \mathrm{~min})$.

A Horiba Jobin-Yvon LabRAM HR800 spectrometer with a $785 \mathrm{~nm}, 300 \mathrm{~mW}$ diode laser as source, Peltier cooled 16-bit CCD, 300 lines/mm grating and $100 \mu \mathrm{m}$ confocal hole, was used for this work. Spectra were acquired in the range from $400 \mathrm{~cm}^{-1}$ to $1800 \mathrm{~cm}^{-1}$ using a $\times 100$ objective (LCPlanN, Olympus), in dry conditions, for 30s two times, from three cell locations: cytoplasm, nucleus and nucleolus, visible under white light illumination. A final data set of 30 points per cell location for each time point, 2, 6, 12, 24, 48 and 72hrs was produced after DOX exposure and for control cells, for each cell line, amounting to a total of over 210 cells per cell line, corresponding to a total data set of 1260 spectra. 


\subsection{Data analysis:}

Raman spectral pre-processing and analysis were performed in Matlab2013 using algorithms developed in house. Prior to analysis, background was subtracted using a NCLS (nonnegatively constrained least squares) algorithm and spectra were smoothed (Savitsky-Golay filter 3th order, 11 points), baseline corrected (fifth order polynomial) and vector normalised. PCA was employed as an unsupervised multivariate approach to analyse data and the effects of doxorubicin in each cell localisation. The order of the PCs denotes their importance to the dataset and PC1 describes the highest amount of variation [13, 17].

PLSR, a statistical regression technique which reduces the dimensionality of the data and correlates information, here represented by the Raman spectra, to time evolution, was employed to track the temporal dependent evolution of the spectral signatures in the subcellular regions [13, 30]. The percentage of variance explained as a function of the number of components was calculated using 10-fold cross validation and from a plot of the percent of variance explained function of number of components, the majority percentage of variance (above 90\%) was found to be explained by the first 3 components. The regression coefficients obtained by PLSR of Raman data regressed against time were plotted and analysed. As a function of frequency, the co-efficients illustrate the spectral features which are influenced by the intracellular interaction of the DOX and the resulting metabolic changes.

ICA was also employed as an extension to PCA. ICA is an unsupervised statistical technique able to identify latent variables called independent components. In the case of Raman microspectroscopy, ICA can be used to identify spectral contributions such as those from substrate, using the same number of ICs as PCs, which can then be removed or studied in their own right $[31,32]$.

\subsection{Nuclear condensation:}

Approximately $1 \times 10^{4}$ cells were allowed to attach on uncoated glass bottom Petri dishes (MatTek Corporation, USA) for two hours, after which they were covered with cell culture medium. After $24 \mathrm{hrs}$ incubation, the medium was removed and samples were rinsed twice with sterile PBS, after which new fresh medium containing DOX corresponding to the inhibitory concentration, $\mathrm{IC}_{50}$, determined by the cytotoxicity assays for each cell line, and adjusted to the cell number [29], was added and cells were incubated for each corresponding time point. 
After incubation, old medium was removed and $2 \mathrm{~mL}$ of Nucred ${ }^{\circledR}$ solution in medium was added and, after 15 to 30 min incubation, samples were rinsed twice with sterile PBS and kept in PBS for live cell imaging using CLSM. Control samples without exposure to DOX were also prepared in parallel, and incubated for 2, 6, 12, 24, 48 and 72hrs.

CLSM images were recorded using an inverted Zeiss LSM 510 Confocal Laser Scanning Microscope equipped with a x60 oil immersion objective. DOX fluorescence was excited with an argon ion laser at $488 \mathrm{~nm}$, and the emission was collected at $530 \mathrm{~nm}$, while Nucred ${ }^{\circledR}$ was measured using 633 and $690 \mathrm{~nm}$, excitation and emission, respectively.

Using ImageJ software, after fluorescence background subtraction, the mean fluorescence intensity of Nucred ${ }^{\circledR}$ was measured for 10 cells for each cell line and each time point.

\subsection{Bcl-2 protein expression:}

Cells ( $3 \times 10^{4} /$ flasks) were cultured in T25 flasks over $24 \mathrm{hrs}$, and then exposed to a DOX dose corresponding to the inhibitory concentration, $\mathrm{IC}_{50}$, adjusted to the cell number [29], determined by cytotoxicity assays for each time point (from $2 \mathrm{hrs}$ to $72 \mathrm{hrs}$ ) and each cell line. After each incubation period, cells were trypsinised and centrifuged in $5 \mathrm{~mL}$ fresh medium at $4^{\circ} \mathrm{C}$ and $1100 \mathrm{rpm}$ for $5 \mathrm{~min}$ and they were then re-suspended in $1 \mathrm{~mL}$ Ice Cold Dulbecco's Phosphate-Buffered Saline (DPBS) buffer and centrifuged at $4{ }^{\circ} \mathrm{C}$ and $2500 \mathrm{rpm}$ for $5 \mathrm{~min}$.

Cells were re-suspended in $750 \mu \mathrm{L}$ ice cold DPBS buffer and transferred to Eppendorf tubes to which $250 \mu \mathrm{L}$ of fixation buffer were added. After $30 \mathrm{~min}$ incubation at $4^{\circ} \mathrm{C}$, the fixed cells were washed twice in perm/wash buffer, centrifuged $\left(2500 \mathrm{Rpm}\right.$ for $5 \mathrm{mn}$ at $\left.4^{\circ} \mathrm{C}\right)$ and then gently re-suspended in $50 \mu \mathrm{L}$ perm/wash buffer, after which $20 \mu \mathrm{L}$ of the antibody were added and the cells were incubated for $60 \mathrm{~min}$ in the dark at $4^{\circ} \mathrm{C}$. The cells were then washed twice in perm/wash buffer, centrifuged $\left(2500 \mathrm{Rpm}\right.$ for $5 \mathrm{mn}$ at $\left.4^{\circ} \mathrm{C}\right)$ to remove unbound antibody and finally re-suspended in $1 \mathrm{~mL}$ stain buffer. 10,000 cells were analysed by Flow Cytometry using a BD Biosciences Accuri C6 Flow Cytometer (Becton Dickinson, Oxford, UK). The Accuri Flow Cytometry software was used for the analysis of Flow Cytometry samples and data processing. 


\section{8. $\gamma \mathbf{H 2 A X}$ expression:}

Cells $\left(10^{6} /\right.$ flask) were cultured in T25 flasks over $24 \mathrm{~h}$, and then exposed to a DOX dose corresponding to the inhibitory concentration, $\mathrm{IC}_{50}$, adjusted to the cell number [29], determined by cytotoxicity assays for each time point (from $2 \mathrm{hrs}$ to $72 \mathrm{hrs}$ ) and each cell line. After each incubation period, cells were trypsinised and centrifuged in $5 \mathrm{~mL}$ fresh medium at $4^{\circ} \mathrm{C}$ and $1100 \mathrm{rpm}$ for $5 \mathrm{~min}$, then were re-suspended with $1 \mathrm{~mL} \mathrm{PBS}$, transferred to an Eppendorf tube and centrifuged at $400 \mathrm{~g}$ for $5 \mathrm{mn}$ at $4{ }^{\circ} \mathrm{C}$. Cells were re-suspended in $200 \mu \mathrm{L}$ of formalin $2 \% \mathrm{v} / \mathrm{v}$ in PBS and incubated for $10 \mathrm{mn}$. If not used immediately, cells can be kept in $1 \mathrm{~mL}$ ice-cold ethanol $70 \%$ and samples and stored at $-20{ }^{\circ} \mathrm{C}$ for up to two weeks or overnight at $4^{\circ} \mathrm{C}$. Cells were then re-suspended in $500 \mu \mathrm{L}$ Triton X-100 0.25\% v/v in PBS and incubated at Room Temperature (RT) for $5 \mathrm{mn}$ or $30 \mathrm{mn}$ at $4^{\circ} \mathrm{C}$, after which cells were centrifuged at $400 \mathrm{~g}$ for $5 \mathrm{mn}$ at RT and re-suspend in $200 \mu \mathrm{L}$ Bovine serum albumin (BSA) solution $(2 \mathrm{mg} / 100 \mathrm{~mL})$ and incubated at RT for $30 \mathrm{mn}$. After centrifugation at $400 \mathrm{~g}$ for $5 \mathrm{mn}$ at RT, cells were re-suspended in $150 \mu \mathrm{L}$ antibody solution diluted in BSA solution 1:500 and incubated at RT for 2 hours or overnight at $4^{\circ} \mathrm{C}$. The cells were then washed thrice in PBS and finally re-suspended in $1 \mathrm{~mL}$ BSA solution. 30,000 cells were analysed by Flow Cytometry using a BD Biosciences Accuri C6 Flow Cytometer (Becton Dickinson, Oxford, UK). The Accuri Flow Cytometry software was used for the analysis of Flow Cytometry samples and data processing.

\section{Results and discussion:}

\subsection{Cytotoxicity assays:}

Figure 1 shows the dose dependent responses of the cytotoxicity assays, AB and MTT, for early (6-24hrs) and late (48hrs-72hrs) stage to DOX exposure, for both cell lines, A549 and Calu-1. Viability is expressed as \% compared to control 3 and the error bars indicate the standard deviation of six independent replicate measurements in triplicate and repeated three times.

For both in vitro assays and for all exposure times, a partial loss of cell population viability is observed for the two cell lines. All viability curves were fitted with Eq.(1) [33]

$\mathrm{V}=\mathrm{V}_{\min }+\left(\mathrm{V}_{\max }-\mathrm{V}_{\min }\right) /\left(1+\left(\mathrm{C} / \mathrm{IC}_{50}\right)^{\mathrm{n}}\right)$

Equation 1 
where $\mathrm{V}$ is the $\%$ viability, $\mathrm{V}_{\min }$ is the minimum viability, $\mathrm{V}_{\max }$ is the maximum viability, $\mathrm{C}$ is the DOX concentration, $\mathrm{n}$ is the Hill slope, and $\mathrm{IC}_{50}$ is the concentration which elicits $50 \%$ of the maximum response. . $\mathrm{IC}_{50}$ values are quoted with the error generated from the fit to all mean data points.

A1.

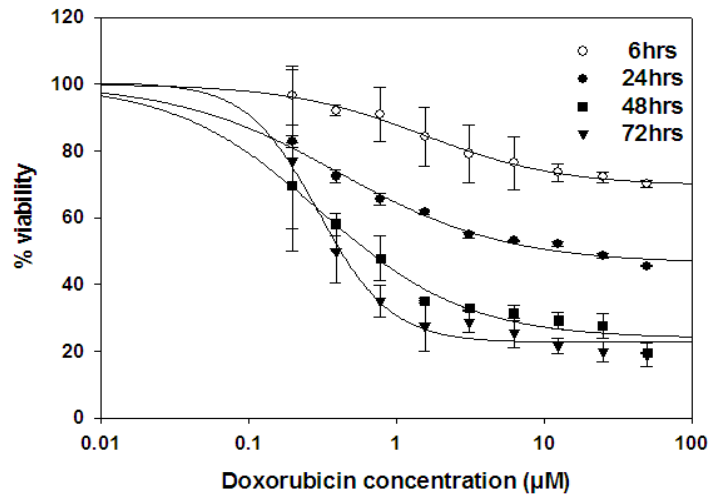

B1.

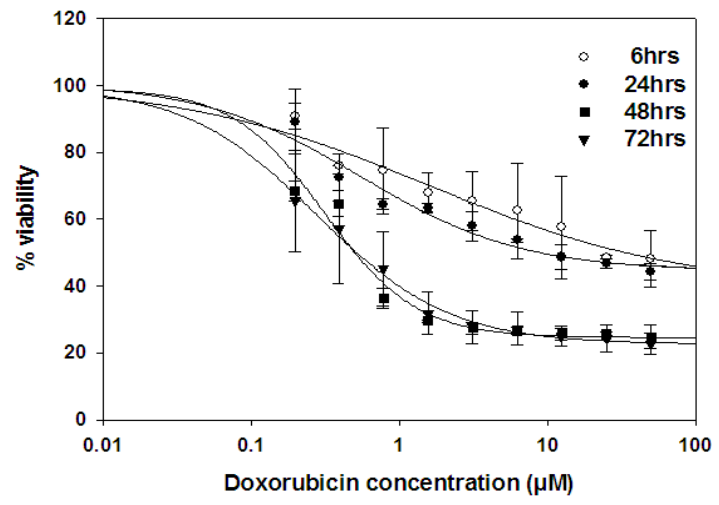

A2.

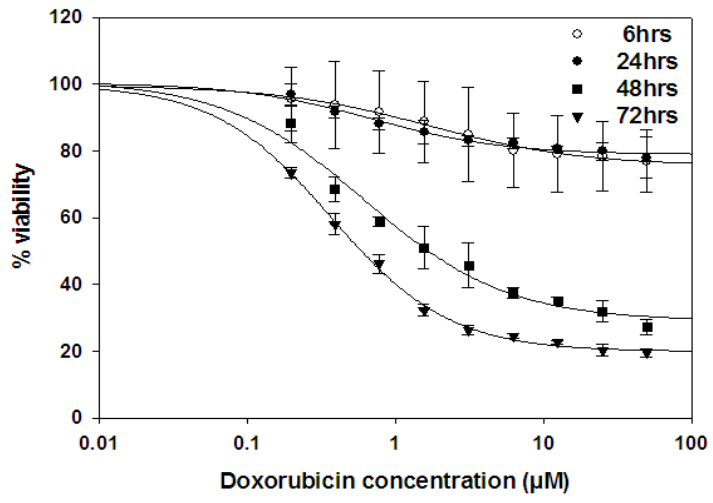

B2.

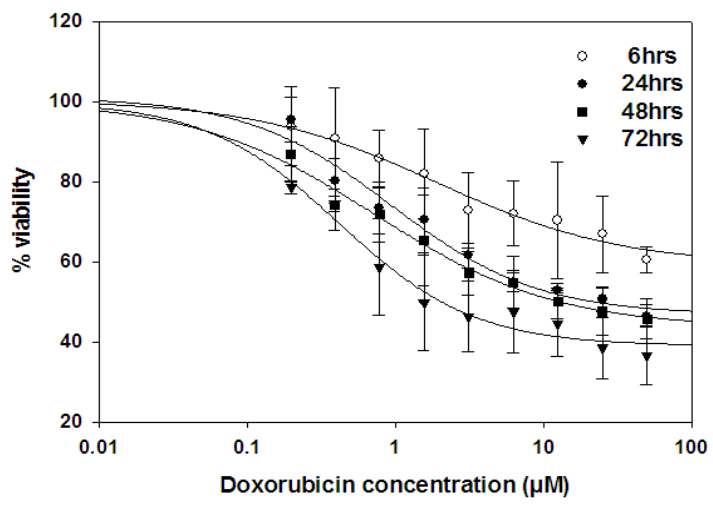

Figure 1: AB in vitro dose dependent cytotoxicity assays of DOX A1. A549 cell line and A2. Calu-1 cell line and MTT in vitro dose dependent cytotoxicity assays of DOX B1. A549 cell line and B2. Calu-1cell line. Viability is expressed as \% compared to control, and the error bars indicate the standard deviation of six independent replicate measurements

The AB and MTT assays for the A549 cell line show similar responses for each time exposure (Figure $1 \mathrm{~A} 1$ and $\mathrm{B} 1$ ) except for the early stage of $6 \mathrm{hrs}$, at which time point $\mathrm{AB}$ appears to be less sensitive than MTT. A slightly different profile is observed for the Calu-1 cell population (Figure $1 \mathrm{~A} 2$ and $\mathrm{B} 2$ ), whereby the $\mathrm{AB}$ assay is seen to be less sensitive for both 6 and 24hrs exposure times. (Table 1) 
Table 1: DOX $\mathrm{IC}_{50}$ concentration determined by the AB and MTT assays for the two cell lines A549 and Calu-1

\begin{tabular}{|c|c|c|c|c|c|c|}
\hline & Time (hrs) & 6 & 24 & 48 & 72 \\
\hline \multirow{4}{*}{ 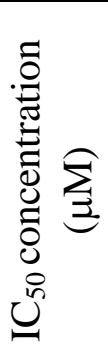 } & & $\mathrm{AB}$ & $1.52 \pm 0.20$ & $0.42 \pm 0.06$ & $0.30 \pm 0.04$ & $0.29 \pm 0.02$ \\
\hline & in & MTT & $1.61 \pm 1.43$ & $0.55 \pm 0.16$ & $0.31 \pm 0.05$ & $0.27 \pm 0.02$ \\
\hline & & $\mathrm{AB}$ & $1.67 \pm 0.29$ & $0.69 \pm 0.13$ & $0.62 \pm 0.12$ & $0.37 \pm 0.01$ \\
\hline & 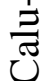 & MTT & $1.90 \pm 0.76$ & $0.90 \pm 0.24$ & $0.72 \pm 0.15$ & $0.41 \pm 0.08$ \\
\hline
\end{tabular}

The AB assay is an expression of general cellular metabolism, while the MTT assay is a reflection of mitochondrial activity [17]. Mitochondrial dysfunction is an early effect of DOX which explains the difference in the two assays for early exposure time points [34].The notably different cytotoxic profiles for the two cell lines, up to $48 \mathrm{hrs}$ exposure to DOX, are consistent with a higher intrinsic resistance of the Calu-1 cell line to the chemotherapeutic drug, whereby Calu-1 cells remain more viable than A549 cells at comparable doses and equivalent exposure times.

The difference in cytotoxicity response between MTT and AB and between the two cell lines suggests different contributions of drug mechanisms of action and relatively different cellular behaviours to the drug treatment, resulting in a delayed response of Calu-1 cell line compared to A549, as indicated by the lower sensitivity of the AB assay up to 24hrs exposure. The MTT assay has been widely used as an indicator of chemosensitivity of cancer cell lines to a chemotherapeutic drug and shows a good correlation of the in vitro results with clinical observations [35-37] and the difference in MTT responses between the two cell lines is indicative of a higher chemosensitivity of A549 cells compared to Calu- 1 . Therefore, the $\mathrm{IC}_{50}$ concentration determined by MTT assay was used for the rest of experiments. 


\subsection{Raman micro-spectroscopy:}

Raman micro-spectroscopy has previously demonstrated that A549 and Calu-1 present different sensitivities to DOX treatment after $24 \mathrm{hrs}$ exposure as a result of different relative contributions of the different mechanisms of action involved [20]. In order to further investigate the subcellular differences at early and late stages of exposure, Raman profiles for both cell lines were compared after 2, 6, 12, 24, 48 and 72hrs exposure to DOX and spectra were taken from the three subcellular compartments, nucleolus, nucleus and cytoplasm (the example of original and pre-processed data of Calu-1 24hrs exposure is shown in Figure S1).

As previously and for comparibility purposes, the $\mathrm{IC}_{50}$ concentration, as determined by the MTT assay, for $24 \mathrm{hrs}$ was used for early exposure from 2 to $24 \mathrm{hrs}$ and for 48 and $72 \mathrm{hrs}$, each corresponding $\mathrm{IC}_{50}$ concentration was used [29].

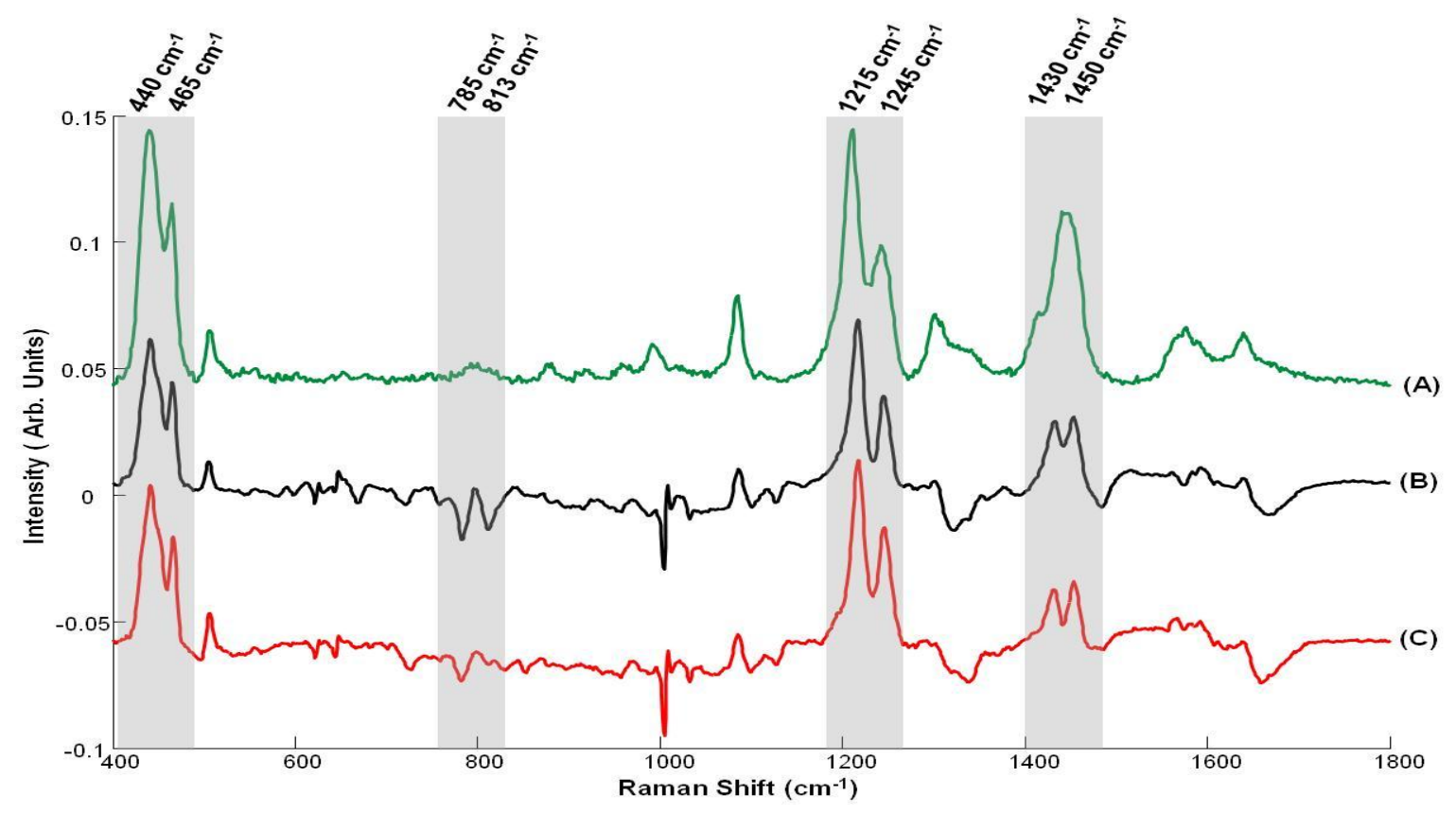

Figure 2: A. Pre-processed Raman spectrum of Doxorubicin dissolved in sterile water, and loading 1 corresponding to PC1 of PCA of Calu-1 control cells versus Calu-1 2hrs exposure of B. nucleolus and $\mathbf{C}$. nucleus 
Multivariate data anlysis, consisting of PCA, PLSR and ICA, was employed in order to analyse in more detail the spectral features due to DOX exposure and compare the cellular effects and responses between the two cell lines and between the different exposure times.

A pairwise PCA of exposed cells for each time point versus control for each cellular compartment was analysed and separation was observed according to PC1 for all time points. As an example PCA of control versus 24hrs exposed for Calu-1 cells is shown in Figure S2. Figure 2 shows the loading of PC1 for the nucleus and nucleolus of Calu-1 cells after $2 \mathrm{hrs}$ exposure, compared to the spectrum of the DOX stock solution.

As seen in Figure 2, obvious DOX features at 440 and $465 \mathrm{~cm}^{-1}$, respectively derived from $\mathrm{C}-\mathrm{C}-\mathrm{O}$ and $\mathrm{C}-\mathrm{O}$ vibrations, and 1085,1215 and $1245 \mathrm{~cm}^{-1}$, related to $\mathrm{C}-\mathrm{O}-\mathrm{H}, \mathrm{C}-\mathrm{O}$ and $\mathrm{C}-$ $\mathrm{H}$, are observed in the spectra of the nucleolar, and nuclear regions, highlighting the DOX uptake into Calu-1 cells after only $2 \mathrm{hrs}$ exposure.

In both nucleolus and nucleus of Calu-1 cells, features at $1430-1450 \mathrm{~cm}^{-1}$ are also observed, corresponding to guanine and cytosine (absent in control cells) and are related to DOX-DNA intercalation inducing damage and/or conformational changes [15]. The same features have been observed after $24 \mathrm{hrs}$ of DOX interaction in A549 cells [20] confirming the early stage DOX-DNA and RNA binding for both cell lines [38]. The decrease in the bands at 785 and $813 \mathrm{~cm}^{-1}$, corresponding respectively to DNA backbone $\mathrm{O}-\mathrm{P}-\mathrm{O}$ and RNA O-P-O phosphodiester bond stretching, confirm an early DOX effect in Calu-1 cells consistent with its main mechanism of action, DNA intercalation, interfering with both DNA and RNA polymerase, inducing DNA replication and RNA transcription blockage [17, 39].

In order to further analyse the DOX cellular kinetics, the DOX peak intensity at $465 \mathrm{~cm}^{-1}$, the loading of PC1 of each time point and cellular compartment for both cancer cells was analysed. This DOX band was chosen due to the minimal influence by the proximity of cellular compounds features. Figure 3 shows the time evolution of this band in each subcellular region for each cell line.Intensity is expressed in percentage function of the highest value observed over all the measurements, that of the A549 nucleolar region after 6hrs exposure. 


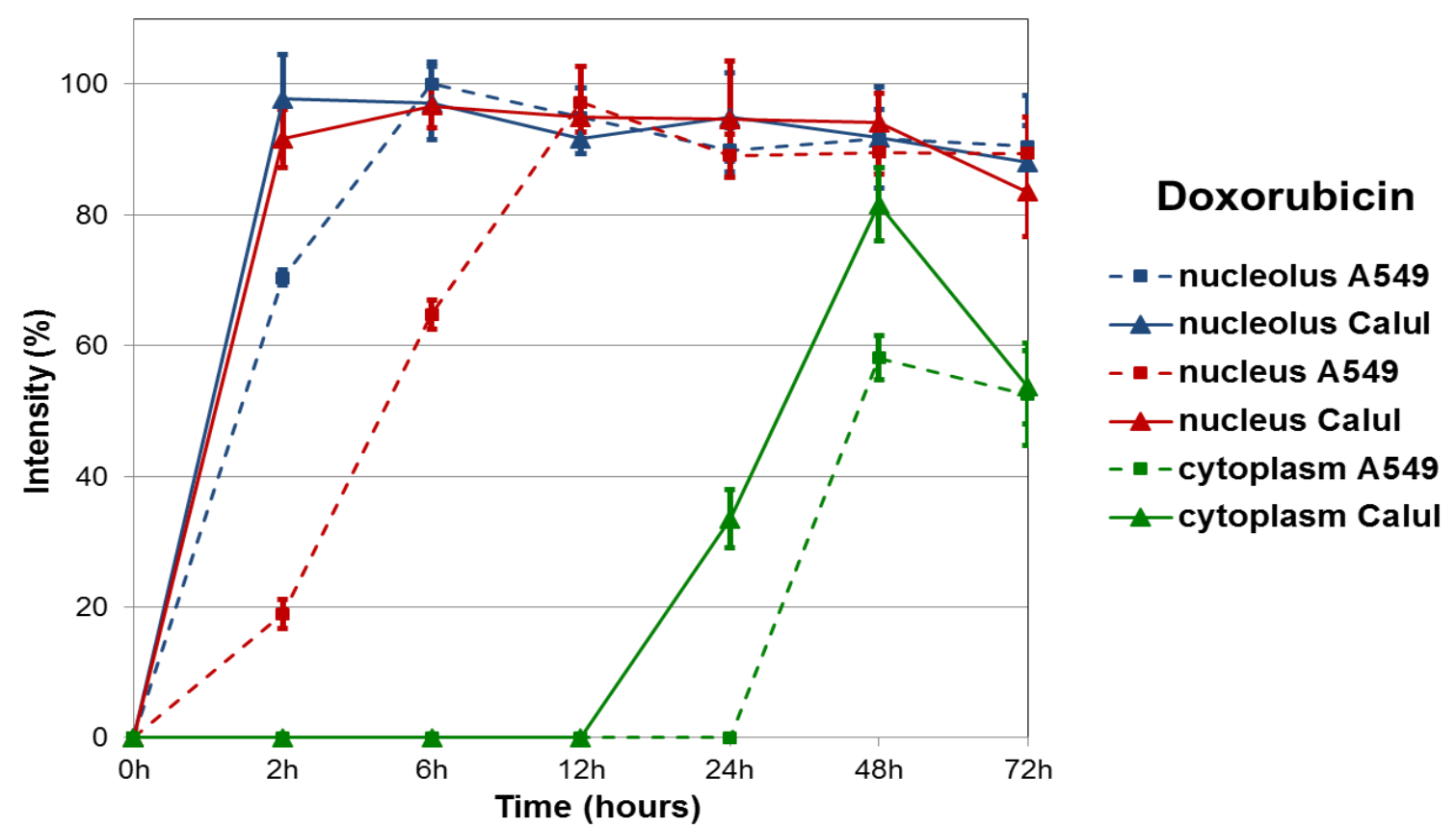

Figure 3: Evolution of DOX, represented by the Raman band at $465 \mathrm{~cm}^{-1}$, as a function of time for the A549 and Calu-1 cell line for each cellular compartment, nucleolus, nucleus and cytoplasm. Intensities are expressed as percentage according to the maximum value over the three cellular compartments and the two cell lines and standard deviation corresponds to the spectral variations of the Raman band over the 30 measurements per location.

For both cell lines, in each subcellular region, (Figure 3) there is a progressive increase of intracellular DOX concentration until a plateau is reached. As previously described for A549 cells, DOX accumulation is initially observed in the nucleoli, reaching saturation at $\sim 6 \mathrm{hrs}$, then in the nucleus, reaching saturation at $\sim 12 \mathrm{hrs}$, before it finally begins to accumulate in the cytoplasm, at $\sim 48 \mathrm{hrs}$, after saturation of nuclear binding sites [40, 41]. Notably, the subcellular accumulation in Calu-1 is much more rapid, saturating at $\sim 2 \mathrm{hrs}$ in the nucleoli, $\sim 6 \mathrm{hrs}$ in the nucleus and is detectable in the cytoplasm after only $\sim 24 \mathrm{hrs}$.

Despite the fact that DOX-DNA intercalation starts at early stages for both cell lines, according to the DOX Raman band, DOX saturation for both nuclear areas happens more rapidly in Calu-1 cells than A549, after which DOX concentration inside the combined nuclear regions becomes approximately constant and accumulation in the cytoplasm due to additional drug taken up by cells is only evident after $\sim 48 \mathrm{hrs}$ for A549 and earlier at $\sim 24 \mathrm{hrs}$ for Calu-1, due, in both cell lines, to nuclear membrane disruption [29]. The saturation levels in each subcellular region are comparable for each cell line, although significantly lower levels of DOX are recorded in the cytoplasmic region of A549. 
A.

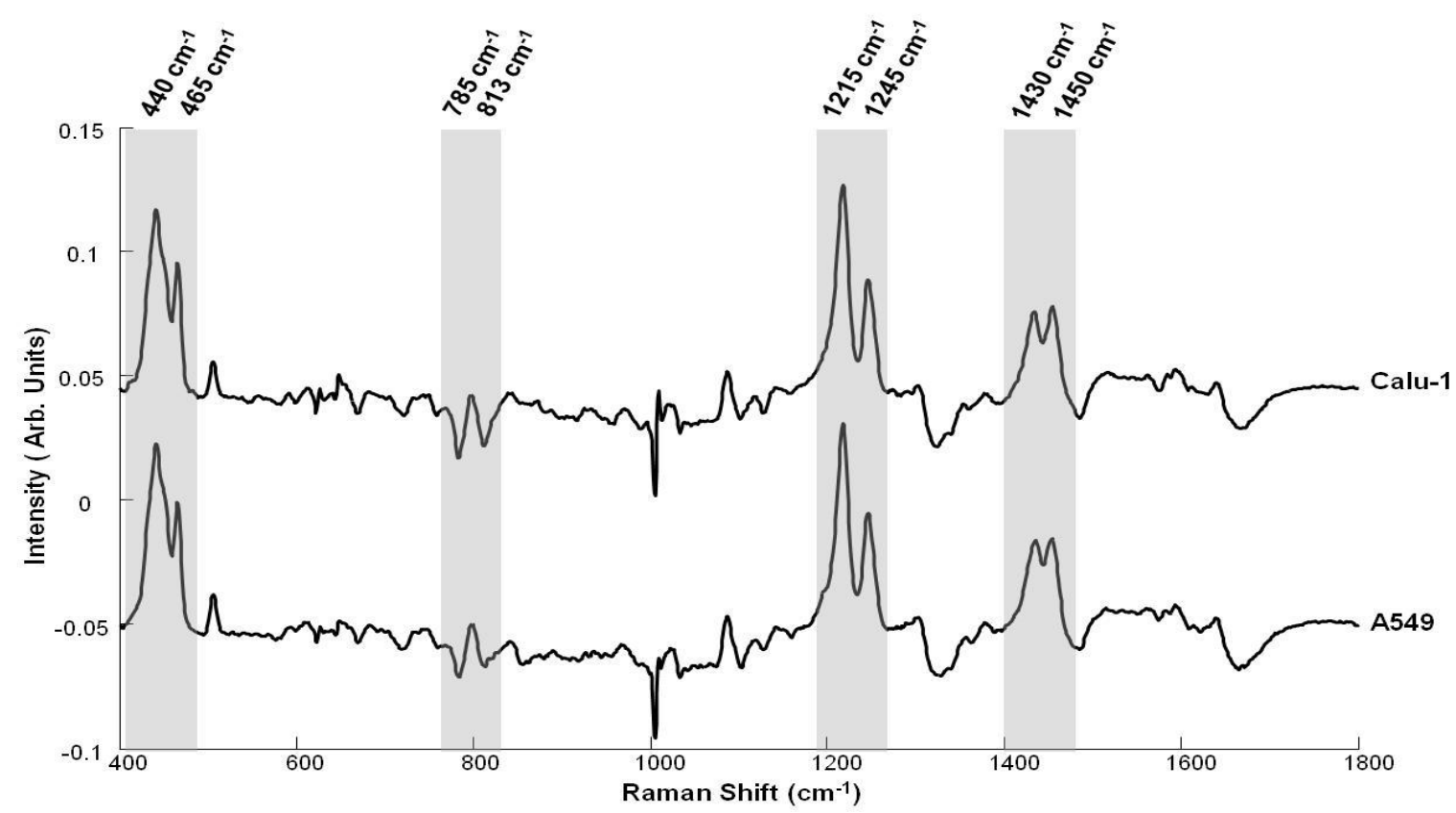

B.

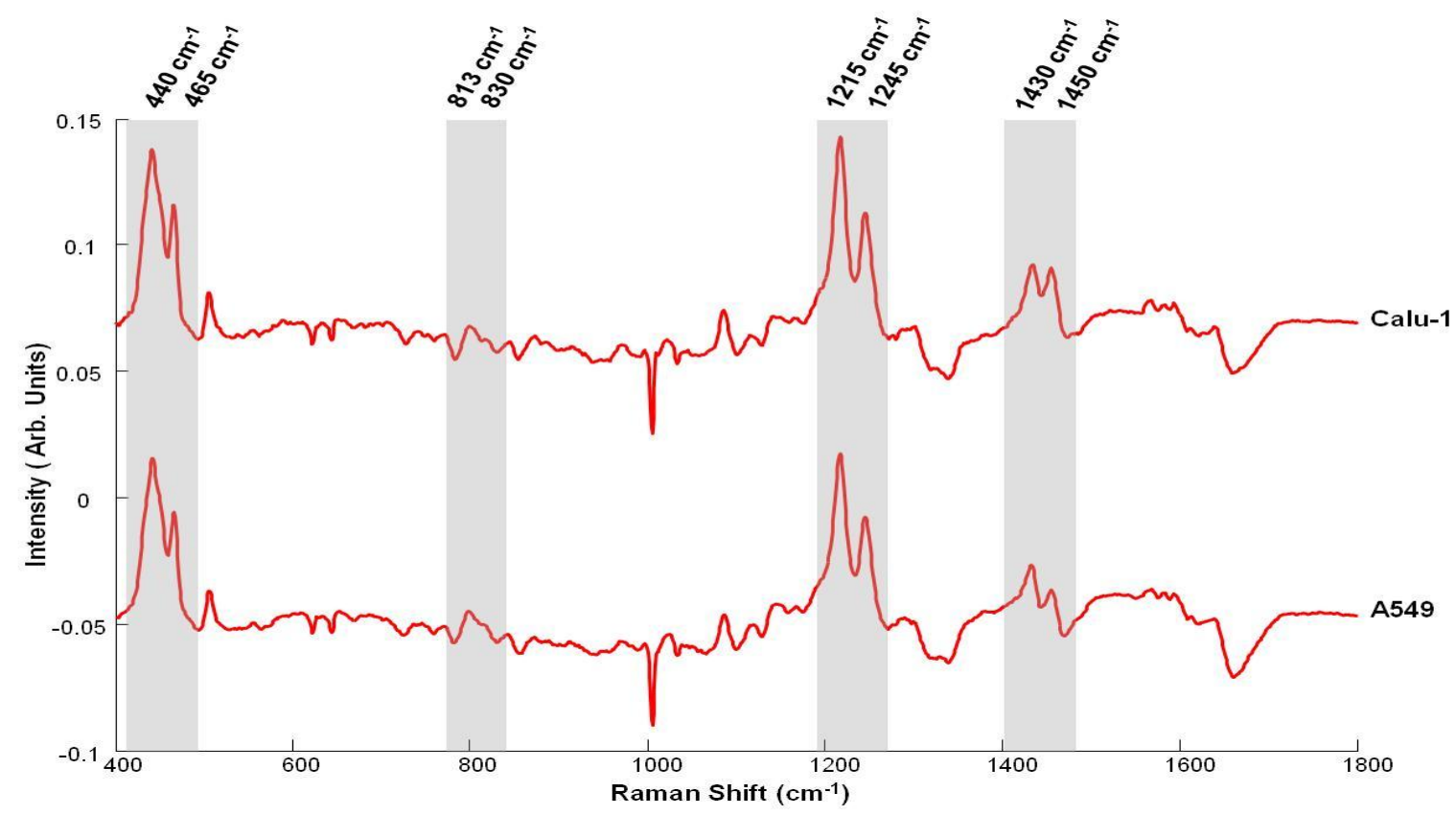

Figure 4: A. Loading 1 of PC1 of control versus exposed cells. A. Nucleolus A549 control versus 6hrs exposure compared to that of nucleolus Calu-1 control versus $2 \mathrm{hrs}$ exposure $\mathbf{B}$. Nucleus A549 control versus $12 \mathrm{hrs}$ exposure and nucleus Calu-1 control versus 6hrs exposure 
In order to compare the DOX mechanism of action and cellular responses, cellular features were analysed in more detail over the time periods before and after DOX saturation for the nuclear and cytoplasmic compartments.

As seen in Figure 4, which shows the loading of PC1of control cells versus exposed in the nuclear regions below the saturation point, almost identical loadings are obtained for both cell lines, including dominant DOX peaks at 440, 465, 1215 and $1245 \mathrm{~cm}^{-1}$. Guanine and cytosine features are prominent, respectively at 1430 and $1450 \mathrm{~cm}^{-1}$, confirming DOX intercalation and RNA interaction in the nucleolus and DNA in the nuclear region, related to DOX binding inducing changes in DNA conformation with a partial transition of DNA from B to A form (change in the ratio between $813 \mathrm{~cm}^{-1}$ and $830 \mathrm{~cm}^{-1}$ bands) and blockage of DNA synthesis and as a consequence a decrease in RNA [16, 17].

Up to the saturation point, the same spectral features assigned to DOX mechanism of action by nuclear intercalation were thus found for A549 and Calu-1, giving a reproducible signature of the binding interaction, which appears to be same for the two cell lines.

In order to track the cellular changes after saturation, PLSR was employed and spectra were regressed against time starting from each saturation point $2 \mathrm{hrs}$ and $6 \mathrm{hrs}$ for Calu-1 cells and $6 \mathrm{hrs}$ and $12 \mathrm{hrs}$ for A549 cells, respectively for nucleolus and nucleus. The regression coefficients obtained are shown in Figure 5.

In both cell lines, for the nucleolar regions (Figure 5A), a notable decrease in features at 728 $\mathrm{cm}^{-1}$ (adenine) $785 \mathrm{~cm}^{-1}$ (cytosine, thymine and DNA backbone O-P-O), $813 \mathrm{~cm}^{-1}$ (RNA O$\mathrm{P}-\mathrm{O}$ stretching), $1095 \mathrm{~cm}^{-1}$ (DNA $\mathrm{PO}_{2}^{-}$symmetric stretching) and $1376 \mathrm{~cm}^{-1}$ (thymine), are consistent with a decrease in nucleic acid contributions due to the DOX mechanism of action by nucleolar interaction, inducing DNA replication blockage, and decrease of RNA features by inhibiting RNA synthesis at the level of rRNA transcription, inhibiting ribosome biogenesis, and, as a consequence, alteration of nucleolar structure [42], size, shape and fragmentation [17, 20, 29], inducing nucleolar stress dependent apoptosis [43, 44]. 
A.

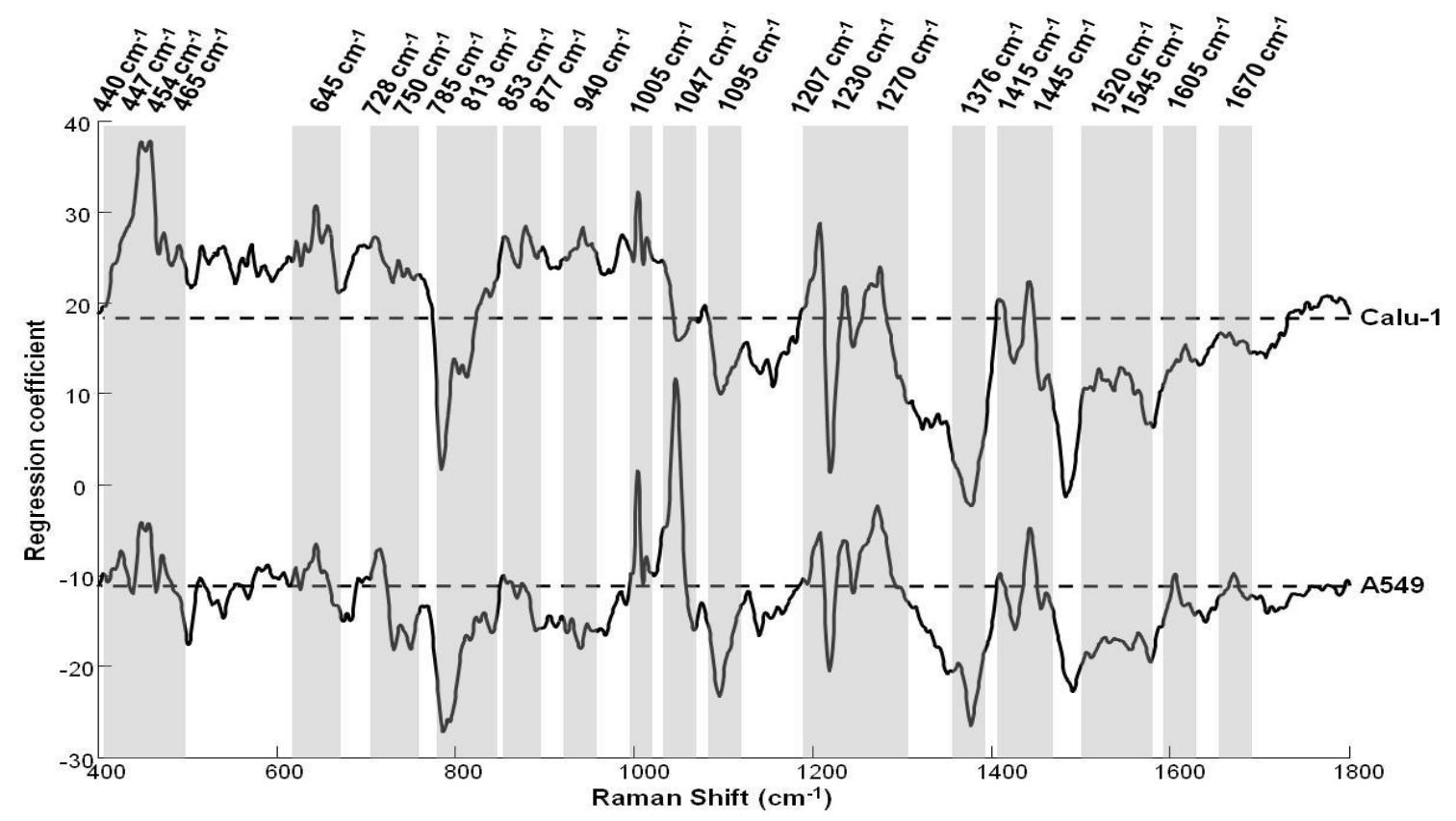

B.

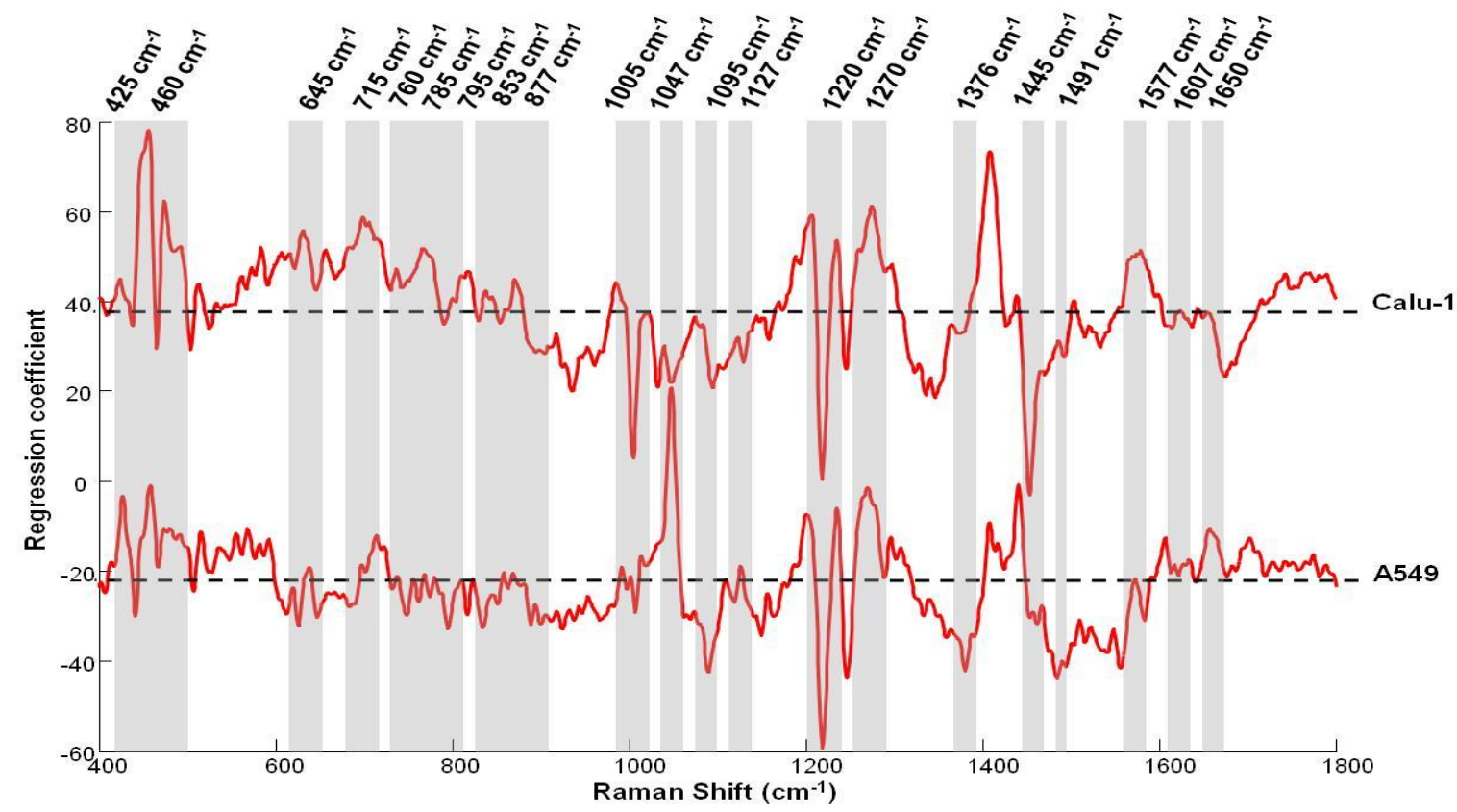

Figure 5: Regression coefficients obtained by PLSR analysis as a function of time after DOX saturation for A549 and Calu-1 cells for A. nucleolus and B. nucleus. 
The increase in proteins and lipids features at respectively $447-454 \mathrm{~cm}^{-1}$ (phenylalanine), (those two bands can be detected clearly due to the fact that, after saturation, the DOX cellular concentration becomes constant and therefore the peaks of the drug itself are no longer evident in the regression), 645-877 $\mathrm{cm}^{-1}$ (C-C tyrosine), $940 \mathrm{~cm}^{-1}$ (C-C stretching of protein) $1207 \mathrm{~cm}^{-1}$ (phenylalanine, tryptophan and tyrosine), $1230 \mathrm{~cm}^{-1}$ (Amide III), 1520$1545 \mathrm{~cm}^{-1}$ (Amide II), $1605 \mathrm{~cm}^{-1}\left(\mathrm{C}=\mathrm{C}\right.$ phenylalanine and tyrosine), $1670 \mathrm{~cm}^{-1}$ (Amide I) $1410-1450 \mathrm{~cm}^{-1}\left(\mathrm{CH}_{2}\right.$ deformation) are consistent with an efflux of anti-apoptotic and repair proteins, as a cellular defense against DOX exposure, and a lipid denaturation of the surronding cytoplasmic membrane [17, 45].

In addition to depletion of spectral features related to DNA in the nuclear area for both cell lines, such as those at $795 \mathrm{~cm}^{-1}, 1095 \mathrm{~cm}^{-1}$ and $1376 \mathrm{~cm}^{-1}$ (Figure 5B), there is an increase in both lipid and protein features, at $645 \mathrm{~cm}^{-1}$ (C-C tyrosine), $715 \mathrm{~cm}^{-1}$ (choline), $760 \mathrm{~cm}^{-1}$ (tryptophan ring breathing), 853-877 $\mathrm{cm}^{-1}$ (tyrosine ring breathing), $1127 \mathrm{~cm}^{-1}$ (C-N stretching), $1445 \mathrm{~cm}^{-1}$ ( $\mathrm{CH}_{2}$ vibrations), $1491 \mathrm{~cm}^{-1}$ (C-H deformation), $1607 \mathrm{~cm}^{-1}$ (tyrosine and phenylalanine ring vibration $\mathrm{C}=\mathrm{C}$ ), and $1650 \mathrm{~cm}^{-1}$ (Amide I), again consistent with a cellular response to DOX associated with anti-apoptotic protein and a synthesis of lipidic vesicules as a way to remove DOX to the extracellular environment.

For both the nucleolus and nucleus in A549 cells, a notable increase in features at $1047 \mathrm{~cm}^{-1}$ (RNA P-O stretching, sugar phosphate $-\mathrm{C}-\mathrm{O}-$ stretching), and $1270 \mathrm{~cm}^{-1}$ (RNA Uracil and cytosine ring stretching) is due to nucleolar fragmentation, resulting in RNA spread [46].

The increase in phenylalanine at $1005 \mathrm{~cm}^{-1}$ seems to be a marker of the late apoptosis stage, at which point nucleolar fragmentation is complete, leaving an empty space with only cellular membrane, while in Calu-1 cells and for both nuclear regions, there is an increase in the 1270 $\mathrm{cm}^{-1}$ band and a decrease in the 1047 and $1005 \mathrm{~cm}^{-1}$ bands, which could be explained by the fact that the nucleolar fragmentation is less advanced in Calu-1 than A549 cells, due to a delay in apoptosis by a higher production of anti-apoptotic proteins. In the nucleus of the Calu-1 cell line, there is also an increase in some DNA bands at $785 \mathrm{~cm}^{-1}$ and $1577 \mathrm{~cm}^{-1}$, which may be due to an increase DNA repair. 
A. (i)

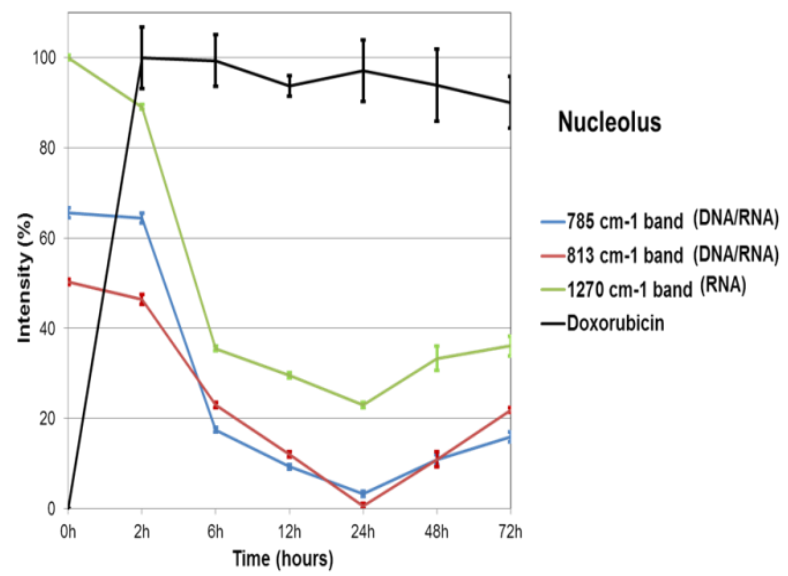

B. (i)

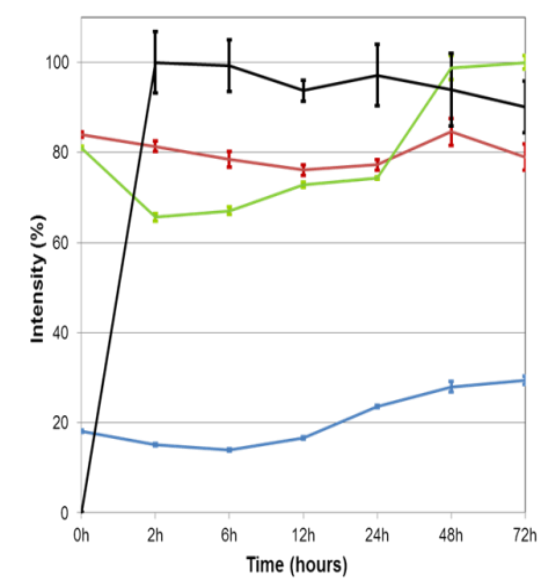

(ii)

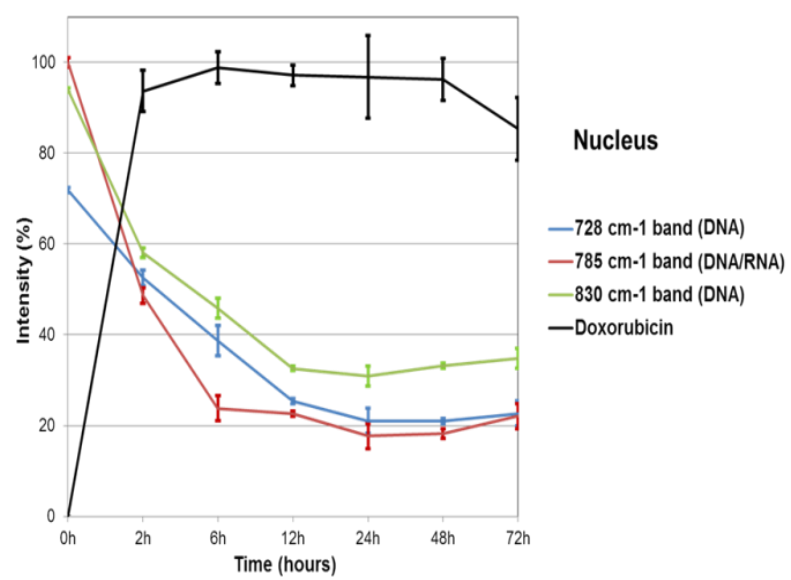

(ii)

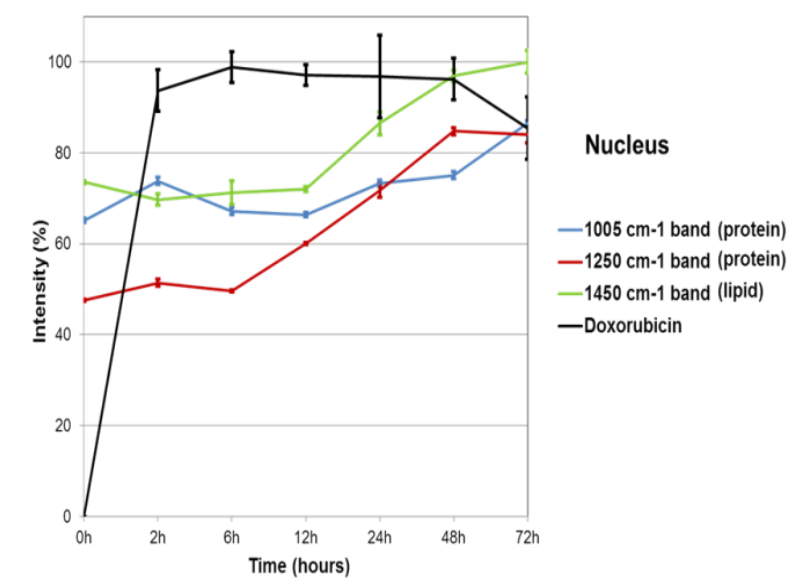

Figure 6: A. Evolution of DOX $\left(465 \mathrm{~cm}^{-1}\right)$ and selected RNA $\left(785,813\right.$ and $\left.1270 \mathrm{~cm}^{-1}\right)$ and DNA $\left(728,785,813\right.$ and $\left.830 \mathrm{~cm}^{-1}\right)$ Raman bands as a function of time B. Evolution of DOX $\left(465 \mathrm{~cm}^{-1}\right)$ and selected protein $\left(645,1005\right.$ and $\left.1250 \mathrm{~cm}^{-1}\right)$ and lipid $\left(1450 \mathrm{~cm}^{-1}\right)$ Raman bands as a function of time for the Calu-1 cell line for each nuclear cellular compartment, (i) nucleolus and (ii) nucleus. Intensities are expressed in percentage according to the maximum value for each nuclear area and standard deviation corresponds to the spectra variations for each band.

In order to highlight the increase of cellular compounds, namely DNA, RNA, proteins and lipids in Calu-1 cells, the evolution of related spectral features in both nucleolus and nucleus, $785 \mathrm{~cm}^{-1}$ and $813 \mathrm{~cm}^{-1}$ (DNARNA), $728 \mathrm{~cm}^{-1}$ and $830 \mathrm{~cm}^{-1}$ (DNA), $645 \mathrm{~cm}^{-1}, 1005 \mathrm{~cm}^{-1}$ and $1250 \mathrm{~cm}^{-1}$ (proteins) and $1450 \mathrm{~cm}^{-1}$ (lipids), as a function of time can be plotted (Figure 6). The band intensities were determined by ICA after DOX substraction. The DOX band was 
determined, as Figure 3, by PCA control vs exposed cells. The evolution of similar bands in A549 cells has been demonstrated previously [29].

A notable decrease in DNA and RNA features is observed (Figure 6 A(i) and A(ii)) at the early stage, concomitant with DOX nuclear accumulation and binding, due to DNARNA alteration, followed by an increase in the same features starting from $\sim 24 \mathrm{hrs}$, as a cellular response by increasing DNA repair. However, the changes appear to be slower in the nucleus and much stronger in the nucleolus, in which a decrease of nucleic acids to less than $10 \%$ is observed, after which they increase to almost the same proportion $\sim 40 \%$. The decrease in nucleic acid features appears also to be stronger in Calu-1 compared to A549 [29]. After DOX saturation, $\sim 2 \mathrm{hrs}$ for the nucleolus and $\sim 6 \mathrm{hrs}$ for the nucleus, proteins and lipids start increasing (Figure $6 \mathrm{~B}(\mathrm{i})$ and $\mathrm{B}(\mathrm{ii})$ ), consistent with the production of anti-apoptitic proteins and a synthesis of lipidic vesicules inducing resistance to apoptosis and as a consequence resistance to the chemotherapeutic drug.

In both nucleolar and nuclear regions, similar kinetics of cellular compounds were found for the two cell lines [29] at the early stages, resulting in a decrease of all cellular features, and after DOX nuclear saturation an increase of protein and lipids is observed, while nucleic features keep decreasing for A549, in contrast to Calu-1 cells which, at prolonged exposures, show signs of recovery by DNA repair, resulting in an increase of nucleic acids features.

In both PLSR regression co-efficient profiles for the cytoplasmic region, for the two cell lines, as shown in Figure 7, there are obvious DOX features at $440-465 \mathrm{~cm}^{-1}$ and $1215-1245$ $\mathrm{cm}^{-1}$. An increase in protein and lipid features is also evident, for example at $524-733 \mathrm{~cm}^{-1}$, corresponding to phosphatidylserine externalization (in healthy cells, aminophospholipids are localised in the inner cytoplasmic membrane) due to membrane alteration $[47,48]$ as an indicator of apoptosis [49, 50], $538 \mathrm{~cm}^{-1}$ (cholesterol ester), related to alteration of endoplasmic reticulum membrane as a marker of apoptosis [29], 576-720 $\mathrm{cm}^{-1}$ (phosphatidylinositol and phosphatidylcholine) related to membrane trafficking, 645-830-853 $\mathrm{cm}^{-1}$ (tyrosine), $1268 \mathrm{~cm}^{-1}$ (Amide III), $1364 \mathrm{~cm}^{-1}$ (tryptophan), 1410-1450 cm $\mathrm{cm}^{-1}\left(\mathrm{CH}_{2}\right.$ deformation) and $1635-1660 \mathrm{~cm}^{-1}$ (Amide I of different conformational forms) indicating a protein and lipid denaturation due to DOX treatment. 


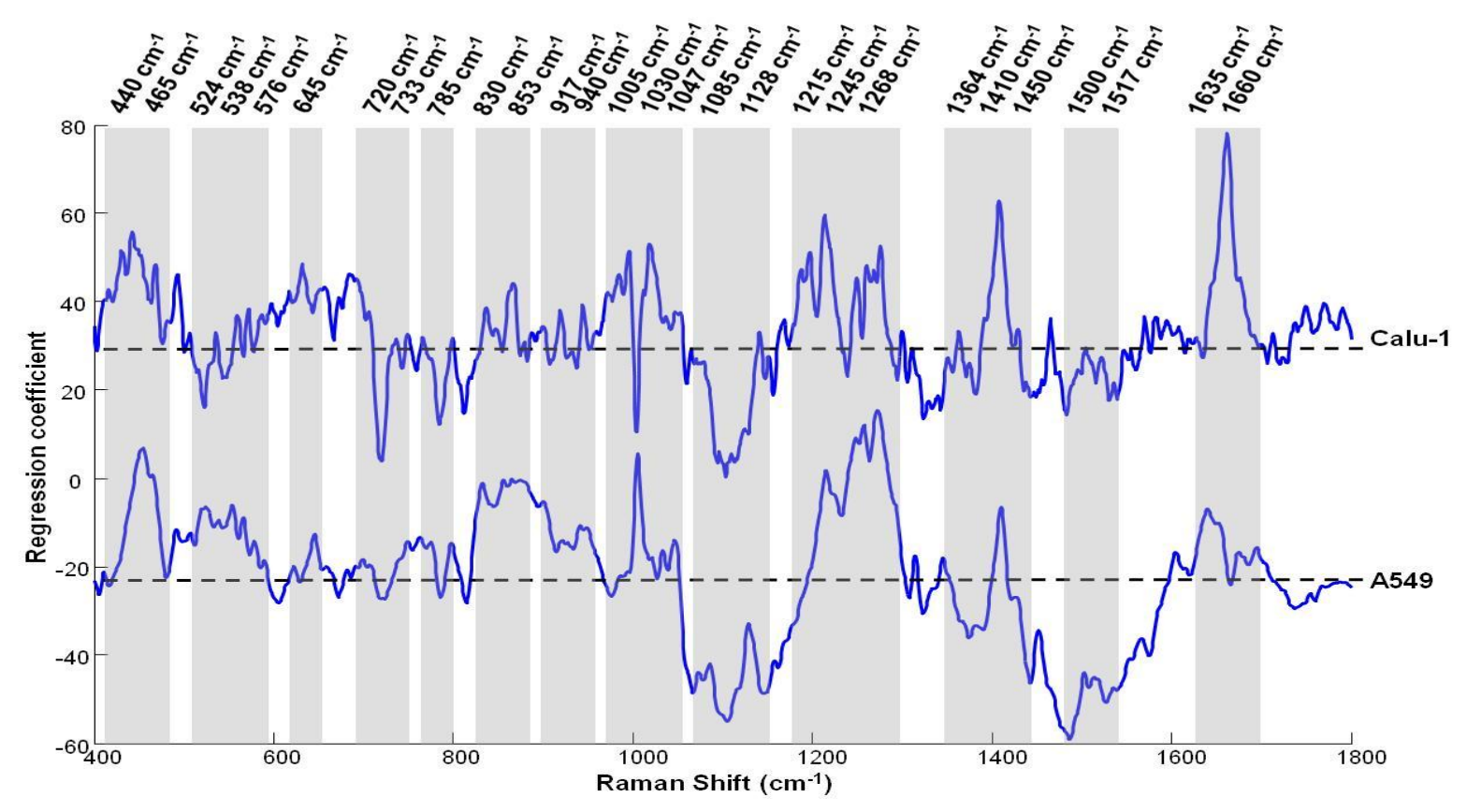

Figure 7: Regression coefficients obtained by PLSR analysis as a function of time over full range of cytoplasmic region for A549 and Calu-1 cells

In addition to the common protein and lipid denaturation indicators between the two cell lines, there is a more notable increase in Calu-1 cells of the bands at $917 \mathrm{~cm}^{-1}$ (Ribose vibration) [51], $940 \mathrm{~cm}^{-1}$ (C-C stretching of protein), $1030 \mathrm{~cm}^{-1}$ (C-H phenylalanine), 1047 $\mathrm{cm}^{-1}$ (RNA P-O stretching, sugar phosphate $-\mathrm{C}-\mathrm{O}-$-stretching) and 1085 and $1128 \mathrm{~cm}^{-1}$ (C-N stretching) corresponding to higher RNA, protein and lipids structure denaturation by oxidative stress due to ROS production, one of the DOX mechanisms of action which has previously been shown to be more prominent in Calu-1 than A549 cells [13, 20].

Therefore, according to the Raman profile, for the two cell lines, DOX appears to have the same binding signatures as seen in loading 1 of PC1 of PCA of control versus exposed cells up to saturation point (Figure 4), but Calu-1cells,despite an earlier DOX cellular accumulation (Figure 3), seem to be more resistant, as indicated by the lower cytotoxic response, due to an efflux of anti-apoptotic protein and an increased DNA repair at the later stages. In order to confirm those observations, bcl-2, an anti-apoptotic protein, and $\gamma \mathrm{H} 2 \mathrm{AX}$, a marker of DNA damage and repair, were measured in both cell lines and the results were correlated to the Raman analysis. 


\subsection{Apoptosis, Bcl-2 protein and DNA repair:}

Apoptosis is a programmed caspase-mediated cell death characterised by morphological cellular changes, including nuclear and cytoplasmic condensation with externalisation of phosphatidylserine and formation of apoptotic bodies, with maintenance of intact cellular membrane. During the later stages, the nucleus further condenses (pyknosis), which is the most characteristic morphological marker of apoptosis, [52, 53] and this is followed by nuclear shrinkage (karyorrhexis) and loss of cellular shape by cytoskeleton cleavage and membrane blebbing $[54,55]$.

Figure 8 shows the evolution of Nucred $^{\circledR}$ fluorescence, as an indicator of nuclear condensation, as a function of time for the two cell lines. In both cases, there is a slight increase in fluorescence in the early stages of drug exposure, and the maximum fluorescence is observed at 24hrs. The maximum is significantly higher for Calu-1 than A549, due to a higher level of chromatin condensation induced by DNA damage due to DOX-DNA interaction [15], confirming the Raman observations (Figure 6).

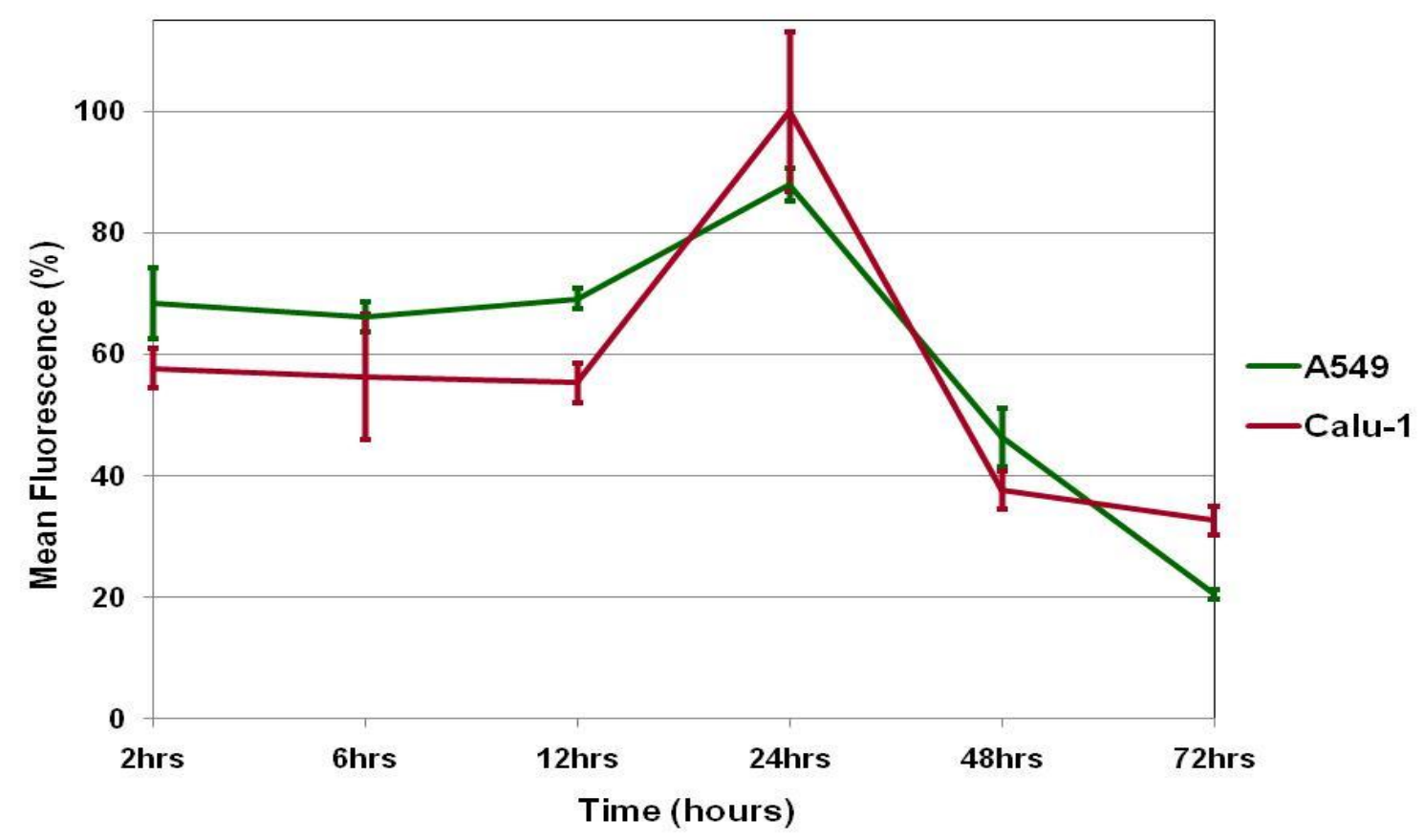

Figure 8: Mean Fluorescence of Nucred ${ }^{\circledR}$ after DOX exposure measured by Confocal Laser Scanning Microscopy and ImageJ for A549 and Calu-1 cells, expressed on percentage according to the maximum value for both cell lines. 
Subsequently, the fluorescence decreases more rapidly in A549 than Calu-1, as a consequence of a higher apoptotic response in Calu-1, via chromatin condensation, [56] confirming the Raman results showing that the two cell lines have the same behaviour at early stages but are different in the later stages. Despite the fact that DOX saturates the nuclear area earlier in Calu-1 than A549, and exhibits higher DNA damage levels, Calu-1 cells appear to be more viable at later stages, which suggest a more effective defence mechanism in Calu-1, increasing cell survival [57, 58], and as a consequence a higher resistance to DOX.

This drug resistance could be explained by either a higher expression of anti-apoptotic protein or an increase in DNA repair, or both.

The expression profile of bcl-2 (B cell lymphoma) an anti-apoptotic protein synthesized as a direct response to DNA damage, [20] as a function of time for the two cell lines is shown in Figure 9. A similar profile is observed, with up regulation followed by a diminution of the bcl-2 protein level as a function of time. Nevertheless, the maximum level of bcl-2 is reached at $12 \mathrm{hrs}$ in the A549 cell line and $48 \mathrm{hrs}$ in Calu-1, with an obviously consistently higher expression for the later stage over the time range. This higher level of bcl-2 protein contributes to cellular resistance to apoptosis inducing a chemotherapeutic drug resistance.

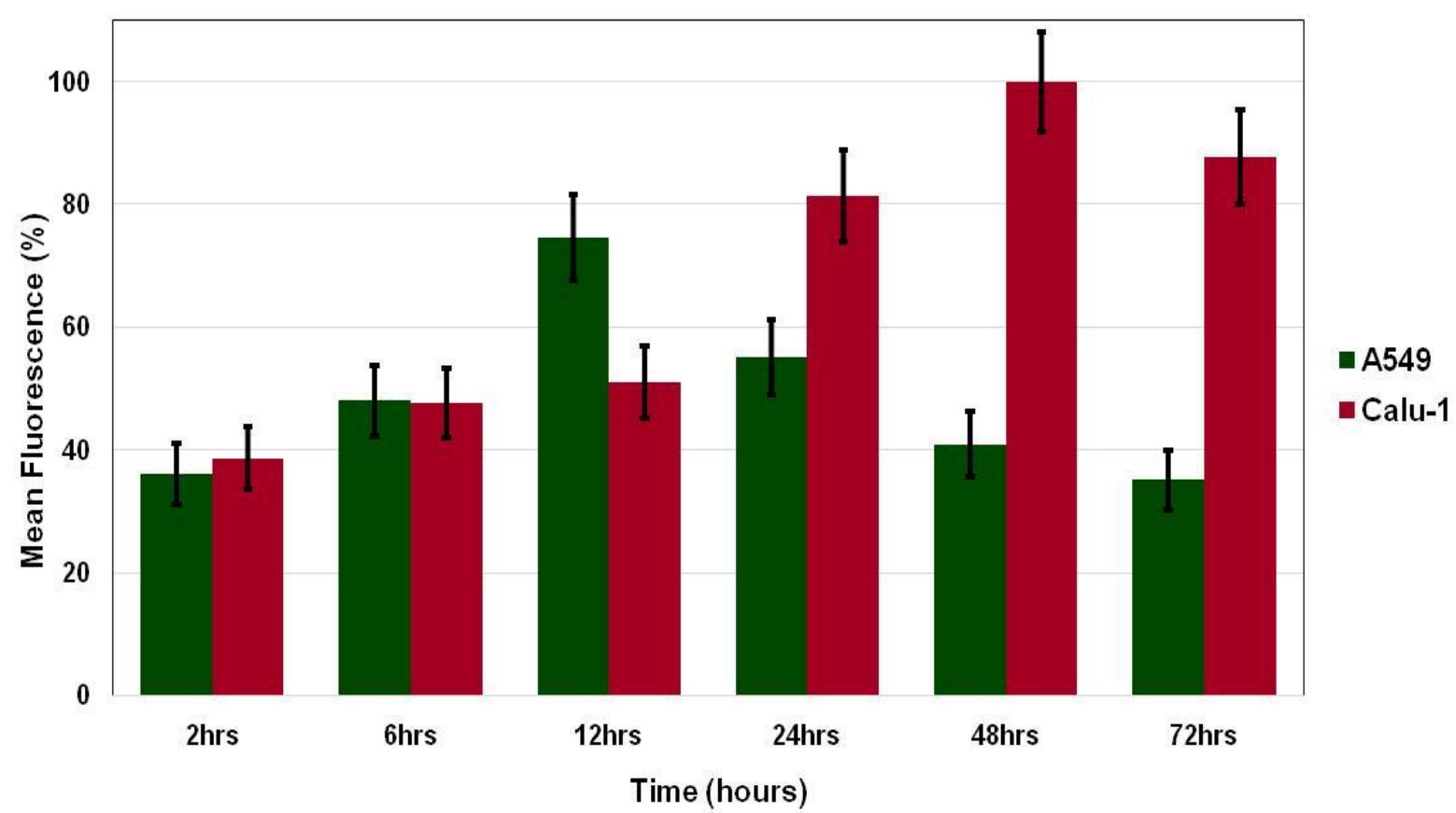


Figure 9: Bcl-2 anti-apoptotic protein level determined by Flow Cytometry after DOX exposure from time point 2 to $72 \mathrm{hrs}$ for A549 and Calu-1 cells, expressed on percentage according to the maximum value for both cell lines.

A specific change in response to DSB is the phosphorylation of $\mathrm{H} 2 \mathrm{AX}$ histone, representing 2 to $25 \%$ of the total $\mathrm{H} 2 \mathrm{~A}$ protein, by members of phosphoinositide 3-kinase related proteins of DDR, into $\gamma \mathrm{H} 2 \mathrm{AX}$ a sensitive indicator of DSB and efficiency of subsequent DNA repair $[24,59,60]$, which is facilated by $\gamma \mathrm{H} 2 \mathrm{AX}$ dephosphorylation by protein phosphatase $2 \mathrm{~A}[26$, 61]. The phosphorylation of $\gamma \mathrm{H} 2 \mathrm{AX}$ is thus an early indicator of DSB [53,62] and the number of $\gamma \mathrm{H} 2 \mathrm{AX}$ nuclear foci is directly correlated with the number of DSBs, [63] which means the more damage there is, the more nuclear foci will be found. Flow Cytometry is a sensitive and rapid technique for the measurement of $\gamma \mathrm{H} 2 \mathrm{AX}$ phosphorylation at cellular level [64].

As seen in Figure 10, showing the $\gamma \mathrm{H} 2 \mathrm{AX}$ expression after DOX exposure for each time point for the two cell lines, there is a progressive increase of $\gamma \mathrm{H} 2 \mathrm{AX}$ until a maximum is reached, followed by a later decrease for the two cell lines. However, for Calu-1, an obvious higher phosphorylation is observed for early stages explained by a higher DNA damage, as observed in the Nucred $^{\circledR}$ (Figure 8) and Raman results (Figure 6) and the maximum expression is observed at $12 \mathrm{hrs}$, while for A549 it is observed at $24 \mathrm{hrs}$, consistent with a more rapid uptake of the drug in the nuclear regions of Calu-1. After the $12 \mathrm{hrs}$ maximum, the $\gamma \mathrm{H} 2 \mathrm{AX}$ levels are seen to decrease more rapidly for the Calu- 1 cells than observed for the A549. The decrease in $\gamma \mathrm{H} 2 \mathrm{AX}$ corresponds to dephosphorylation of this histone after DNA repair and this dephosphorylation is proportional to DNA repair mechanisms which occur over time to repair the DNA damage. In this case, it appears that there is an increased tolerance to DNA damage and a higher degree of DNA repair in Calu-1 cells than in A549, confirming the Raman observations (Figure 5 and 6) showing a recovery in DNA features for Calu-1 at the later stages inducing a delay and resistance to apoptosis. 


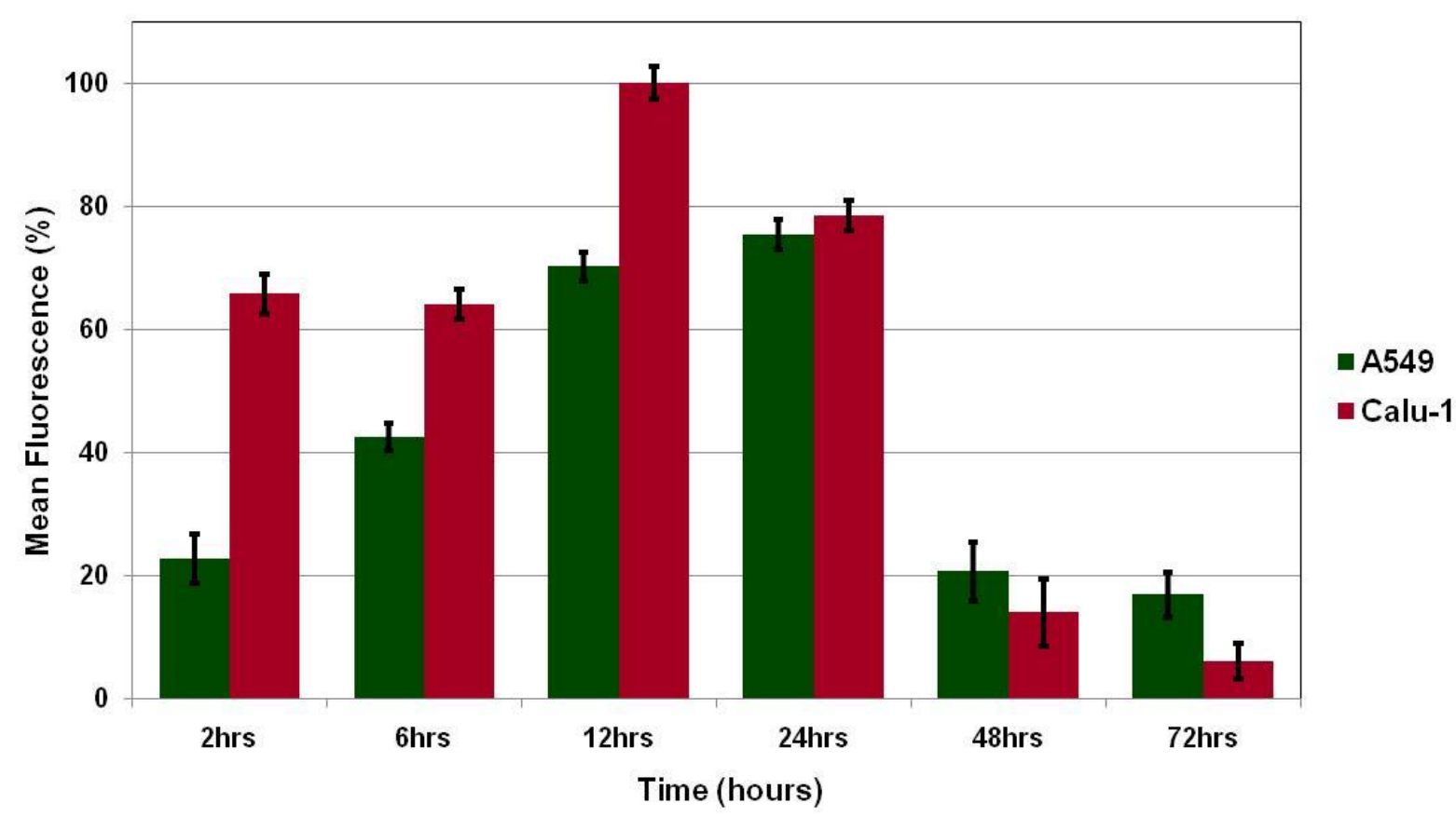

Figure 10: Mean Fluorescence of $\gamma \mathrm{H} 2 \mathrm{AX}$ after DOX exposure measured by Flow Cytometry for A549 and Calu-1 cells, expressed on percentage according to the maximum value for both cell lines.

Raman micro spectroscopic results elucidate both drug kinetics and mechanism of action, giving a fingerprint of chemical binding, nucleic acid intercalation, and signatures of cellular resistance associated with tolerance to DNA damage, synthesis of anti-apoptotic protein and DNA repair. Multivariate data analysis (PCA, ICA and PLSR) indicates that the two cell lines have different rates of uptake, resulting in earlier saturation of both nucleolar and nuclear compartments for the Calu-1 cell line, and an earlier appearance of DOX in cytoplasm due to nuclear disruption.

It has been reported that cellular uptake of the weakly-basic drug DOX is dependent on the extracellular $\mathrm{pH}$ [65], and thus, the lower $\mathrm{pH}$ of the DMEM-F12 (pH 7-7.4) compared to that of RPMI ( $\mathrm{pH} 8.2 \pm 0.3$ ) may be the cause of a slower uptake of DOX in A549 cells compared to Calu-1. However, the degree of accumulation in the nulei and nucleoli is seen to be similar in the two cell lines, indicating that there are no intracellular $\mathrm{pH}$ dependent differences between the cell lines [65]. After passive diffusion through the cellular cytoplasmic membrane due to its high lipophilicity, DOX binds directly to proteasomal transporters and translocates into the combined nuclear area whereupon it binds to nucleic acids and rapidly saturates the nucleolar region [29]. Cellular efflux regulators can also impact on the rate of 
accumulation in the cell nucleus [66], although the enhanced DOX cellular uptake observed in Calu-1 compared to A549 cells should be associated with higher cytotoxicity in Calu-1 cells [67]. The fact that the inverse is observed is a strong indication that the cellular resistance has origin in higher tolerance to DNA damage with higher synthesis of antiapoptotic proteins.

Critically, the early signatures of interactin of the drug, associated with the drug interaction, are comparable in the two cell lines, indicating that the methodology can be developed for label free, prescreening of drug candidates in vitro.

Regression against time after DOX saturation in the respective nuclear regions shows essentially the subsequent cellular responses to DOX exposure, including DNARNA damage leading to apoptosis and the different cellular reactions such as synthetis of lipidic vesicules and increase in protien features. Despite the fact that same binding signature was found for the two cell lines, Calu-1 cells show higher resistance, correlated with notably different dose dependent cytotoxic response profiles, suggesting a higher viability, firstly by increased tolerence to DNA damage manifest as a decrease of DNA to 10\% of control compared to $40 \%$ in A549, confirmed by higher nuclear condensation according to the Nucred ${ }^{\circledR}$ assay, and larger amount of $\gamma \mathrm{H} 2 \mathrm{AX}$ at early exposure points and secondly, higher expression of antiapoptotic proteins, principaly bcl-2 one and higher DNA repair, confirmed by $\mathrm{H} 2 \mathrm{AX}$ dephosphorylation at later stages. 


\section{Conclusion:}

Raman micro-spectroscopy has already demonstrated its potential to track in vitro the kinetics and accumulation of the chemotherapeutic drug DOX at a subcellular level and to identify its different mechanism of action [17, 20, 29]. The present study not only confirms its ability to monitor drug cellular kinetics and mechanism of action but also to differentiate between cellular reactions and resistance. In fact, the two lung cell lines exhibit different behaviours with higher nuclear condensation, measured by Nucred ${ }^{\circledR}$, and a higher resistance of Calu-1, despite the similar drug chemical binding, with a higher tolerance to DNA damage and implications of DNA repair mechanism confirmed by expression of $\gamma \mathrm{H} 2 \mathrm{AX}$ protein, and resistance to apoptosis by bcl-2 protein expression.

Thus, Raman micro-spectroscopy is able not only to track the subcellular accumulation of the drug as function of time but also to identify its mechanism of action, the subsequent cellular response and to differentiate cellular resistance. Therefore, it can be used as an in vitro, preclinical screening technique for drug mechanism of action and efficacy in order to aid preclinical drug development. Furthermore, the ability of Raman micro-spectroscopy to monitor subcellular processes associated with drug resistances suggests its potential as an in vitro companion diagnostics technique to screen for personalised therapies.

\section{Acknowledgement:}

This work was supported by Science Foundation Ireland Principle Investigator Award 11/PI/1108. 


\section{References:}

[1] J.A. DiMasi, H.G. Grabowski, and R.W. Hansen, J Health Econ 47, 20-33 (2016).

[2] J.A. DiMasi, H.G. Grabowski, and R.W. Hansen, J Health Econ 22, 151-185 (2003).

[3] E. Petrova, Innovation in the Pharmaceutical Industry: The Process of Drug Discovery and Development, in Innovation and Marketing in the Pharmaceutical Industry: Emerging Practices, Research, and Policies. 2013, Springer New York: New York, NY.p. 19-81.

[4] P. Szymański, M. Markowicz, and E. Mikiciuk-Olasik, Int J Mol Sci 13, 427-452 (2012).

[5] A. Jemal, M.M. Center, C. DeSantis, and E.M. Ward, Cancer Epidemiol Biomarkers Prev 19, 1893 (2010).

[6] J. Ferlay, I. Soerjomataram, R. Dikshit, S. Eser, C. Mathers, M. Rebelo, D.M. Parkin, D. Forman, and F. Bray, Int J Cancer 136, E359-386 (2015).

[7] A.S. Tsao, G.V. Scagliotti, PA.Jr. Bunn, D.P. Carbone, G.W. Warren, C. Bai, H.J. de Koning, A.U. Yousaf-Khan, A. McWilliams, M.S. Tsao, P.S. Adusumilli, R. RamiPorta, H. Asamura, P.E. Van Schil, G.E. Darling, S.S. Ramalingam, D.R. Gomez, K.E. Rosenzweig, S. Zimmermann, S. Peters, S.H. Ignatius Ou, T. Reungwetwattana, P.A. Janne, T.S. Mok, H.A. Wakelee, R. Pirker, J. Mazières, J.R. Brahmer, Y. Zhou, R.S. Herbst, V.A. Papadimitrakopoulou, M.W. Redman, M.W. Wynes, D.R. Gandara, R.J. Kelly, F.R. Hirsch, and H.I. Pass, J Thorac Oncol 11, 613-638 (2016).

[8] L. Cabeza, R. Ortiz, J. Prados, A.V. Delgado, M.J. Martín-Villena, B. Clares, G. Perazzoli, J.M. Entrena, C. Melguizo, and J.L. Arias, Eur J Pharm Sci 102, 24-34 (2017).

[9] Y.L. Chen, M.C. Chang, and W.F. Cheng, Cancer Lett doi: 10.1016/j.canlet.2017.01.040, (2017).

[10] C.L. Overby and P. Tarczy-Hornoch, Per Med 10, 453-462 (2013).

[11] S.H. Cho, J. Jeon, and S.I. Kim, J Breast Cancer 15, 265-272 (2012).

[12] H.J. Butler, L. Ashton, B. Bird, G. Cinque, K. Curtis, J. Dorney, K. Esmonde-White, N.J. Fullwood, B. Gardner, P.L. Martin-Hirsch, M.J. Walsh, M.R. McAinsh, N. Stone, and F.L. Martin, Nat Protocols 11, 664-687 (2016).

[13] E. Efeoglu, A. Casey, and H.J. Byrne, Analyst 141, 5417-5431 (2016).

[14] H.J. Byrne, M. Baranska, G.J. Puppels, N. Stone, B. Wood, K.M. Gough, P. Lasch, P. Heraud, J. Sule-Suso, and G.D. Sockalingum, Analyst 140, 2066-2073 (2015). 
[15] A. Rabbani, R.M. Finn, and J. Ausio, Bioessays 27, 50-56 (2005).

[16] D. Agudelo, P. Bourassa, G. Bérubé, and H.A. Tajmir-Riahi, Int J Biol Macromol 66, 144-150 (2014).

[17] Z. Farhane, F. Bonnier, A. Casey, and H.J. Byrne, Analyst 140, 4212-4223 (2015).

[18] Y. Gu, J. Li, Y. Li, L. Song, D. Li, L. Peng, Y. Wan, and S. Hua, Int J Nanomedicine 11, 5757-5770 (2016).

[19] J. Gautier, E. Munnier, M. Soucé, I. Chourpa, and L. Douziech Eyrolles, Anal Bioanal Chem 407, 3425-3435 (2015).

[20] Z. Farhane, F. Bonnier, M.A. Maher, J. Bryant, A. Casey, and H.J. Byrne, J Biophotonics 10, 151-165 (2017).

[21] M. Hasanzadeh and N. Shadjou, Mater Sci Eng C Mater Biol Appl 61, 1002-1017 (2016).

[22] F. Yang, C.J. Kemp, and S. Henikoff, Mutal Res 773, 9-15 (2015).

[23] W.E. Ross and M.O. Bradley, Biochim Biophys Acta 654, 129-134 (1981).

[24] T. Ohnishi, E. Mori, and A. Takahashi, Mutat Res 669, 8-12 (2009).

[25] I. Brandsma and D.C. Gent, Genome Integr 3, 9-9 (2012).

[26] T. Helleday, E. Petermann, C. Lundin, B. Hodgson, and R.A. Sharma, Nat Rev Cancer 8, 193-204 (2008).

[27] A. Ivashkevich, C.E. Redon, A.J. Nakamura, R.F. Martin, and O.A. Martin, Cancer Lett 327, 123-133 (2012).

[28] E.C. de Bruin and J.P. Medema, Cancer Treat Rev 34, 737-749 (2008).

[29] Z. Farhane, F. Bonnier, and H.J. Byrne, Anal Bioanal Chem 409, 1333-1346 (2017).

[30] M.E. Keating, H. Nawaz, F. Bonnier, and H.J. Byrne, Analyst 140, 2482-2492 (2015).

[31] M. Boiret, D.N. Rutledge, N. Gorretta, Y.M. Ginot, and J.M. Roger, J Pharm Biomed Anal 90, 78-84 (2014).

[32] V. Vrabie, C.Gobinet, O. Piot, A. Tfayli, P. Bernard, R. Huez, and M. Manfait, Biomed Signal Process Control 2, 40-50 (2007).

[33] J.W. Black and P. Leff, Proc R Soc Lond B Biol Sci 220, 141 (1983).

[34] P.S. Green and C. Leeuwenburgh, Biochim Biophys Acta 1588, 94-101 (2002).

[35] J. Carmichael, J.B. Mitchell, W.G. DeGraff, J. Gamson, A.F. Gazdar, B.E. Johnson, E. Glatstein, and J.D. Minna, Br J Cancer 57, 540-547 (1988).

[36] J.D. Burton, Methods Mol Med 110, 69-78 (2005).

[37] B. G. Campling, J. Pym, H.M. Baker, S.P. Cole, and Y.M. Lam, Br J Cancer 63, 75-83 (1991). 
[38] D. Agudelo, P. Bourassa, M. Beauregard, G. Bérubé, and H.A.Tajmir-Riahi, PLoS ONE 8, e69248 (2013).

[39] C.F. Thorn, C. Oshiro, S. Marsh, T. Hernandez-Boussard, H. McLeod, T.E. Klein, and R.B. Altman, Pharmacogenet Genomics 21, 440-446 (2011).

[40] A.W. El-Kareh and T.W. Secomb, Neoplasia 7, 705-713 (2005).

[41] A. Zenebergh, R. Baurain, and A. Trouet, Eur J Cancer Clin Oncol 20, 115-121 (1984).

[42] I. Orsolic, D. Jurada, N. Pullen, M. Oren, A.G. Eliopoulos, and S. Volarevic, Semin Cancer Biol 37-38, 36-50 (2016).

[43] S.J. Woods, K.M. Hannan, R.B. Pearson, and R.D. Hannan, Biochim Biophys Acta 1849, 821-829 (2015).

[44] D. Avitabile, B. Bailey, C.T. Cottage, B. Sundararaman, A. Joyo, M. McGregor, N. Gude, S. Truffa, A. Zarrabi, M. Konstandin, M. Khan, S. Mohsin, M. Volkers, H. Toko, M. Mason, Z. Cheng, S. Din, R.Jr. Alvarez, K. Fischer, and M.A. Sussman, Proc Natl Acad Sci U S A 108, 6145-6150 (2011).

[45] S. Verrier, I. Notingher, J.M. Polak, and L.L. Hench, Biopolymers 74, 157-162 (2004).

[46] N.T. Chen, C.Y. Wu, C.Y. Chung, Y. Hwu, S.H. Cheng, C.Y. Mou, and L.W. Lo, PLoS ONE 7, e44947 (2012).

[47] D. Wlodkowic, W. Telford, J. Skommer, and Z. Darzynkiewicz, Methods Cell Biol 103, 55-98 (2011)

[48] V.E. Kagan, J.P. Fabisiak, A.A. Shvedova, Y.A. Tyurina, V.A. Tyurin, N.F. Schor, and K. Kawai, FEBS Letters 477, 1-7 (2000).

[49] U. Ziegler and P. Groscurth, Physiology 19, 124 (2004).

[50] S.H. Lee, X.W. Meng, K.S. Flatten, D.A. Loegering, and S.H. Kaufmann, Cell Death Differ 20, 64-76 (2013).

[51] Z. Movasaghi, S. Rehman, and I.U. Rehman, Appl Spectrosc Rev 42, 493-541 (2007).

[52] S. Elmore, Toxicol Pathol 35, 495-516 (2007).

[53] D. Plesca, S. Mazumder, and A. Almasan, Methods Enzymol 446, 107-122 (2008).

[54] S.L. Fink and B.T. Cookson, Infect Immun 73, 1907-1916 (2005).

[55] A. Saraste and K. Pulkki, Cardiovasc Res 45, 528-537 (2000).

[56] R.C. Burgess, B. Burman, M. J. Kruhlak, and T. Misteli, Cell Rep 9, 1703-1717 (2014).

[57] W.P. Roos, A.D. Thomas, and B. Kaina, Nat Rev Cancer 16, 20-33 (2016).

[58] W.P. Roos and B. Kaina, Trends Mol Med 12, 440-450 (2006).

[59] M. Podhorecka, A. Skladanowski, and P. Bozko, J Nucleic Acids 2010, 9 (2010). 
[60] N. Srivastava, S. Gochhait, P. de Boer, R.N. Bamezai, and N.K. Rameshwar, Mutat Res Rev Mutat Res 681, 180-188 (2009).

[61] L.J. Kuo and L.X. Yang, In vivo 22, 305-309 (2008).

[62] O. Fernandez-Capetillo, A. Lee, M. Nussenzweig, and A. Nussenzweig, DNA Repair 3, 959-967 (2004).

[63] A. Takahashi and T. Ohnishi, Cancer Lett 229, 171-179 (2005).

[64] A. Sharma, K. Singh, and A. Almasan, Methods Mol Biol 920, 613-626 (2012).

[65] P. Swietach, A. Hulikova, S. Patiar, R.D. Vaughan-Jones, and A.L. Harris, PLOS ONE 7, e35949 (2012).

[66] F. Shen, S. Chu, A.K. Bence, B. Bailey, X. Xue, P.A. Erickson, M.H. Montrose, W.T. Beck, and L.C. Erickson, Journal of Pharmacology and Experimental Therapeutics 324, 95 (2007).

[67] K. Kik, M. Wasowska-Lukawska, I. Oszczapowicz, and L. Szmigiero, Anticancer Res 29, 1429 (2009). 


\section{Graphical Abstract:}

Raman micro-spectroscopy is employed to investigate and compare Doxorubicin mechanisms of action, its kinetics and different cellular resistances of cancer cell lines A549 and Calu-1. Results show the potential of Raman not only to distinguish the different mechanisms of action at subcellular level but also to elucidate drug resistance by increase tolerance to DNA damage and higher DNA repair.
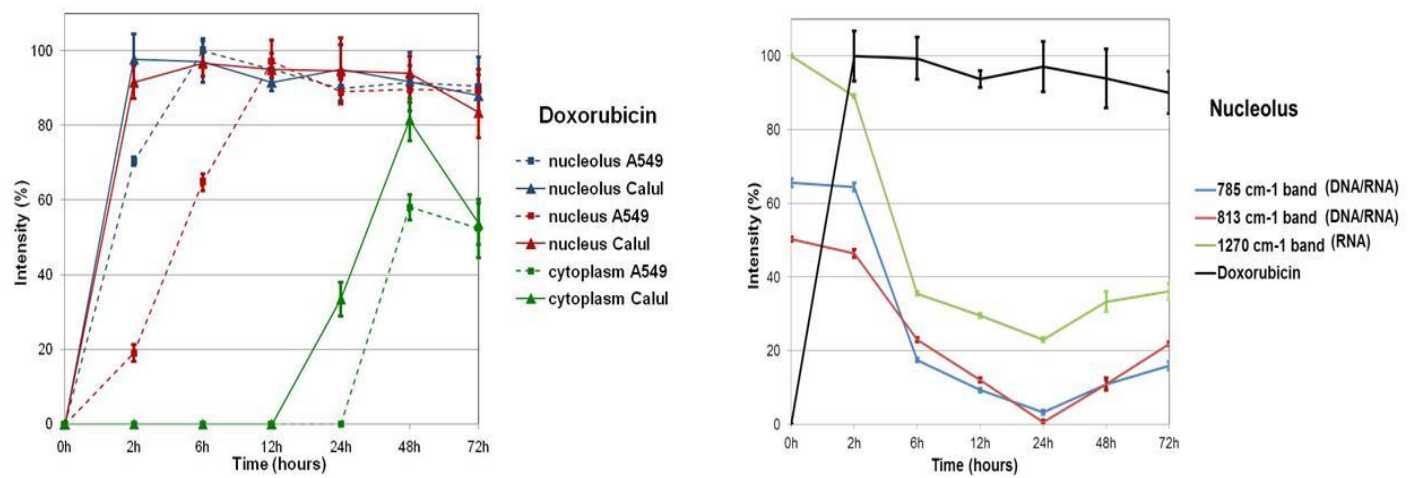